\title{
Husserl's Critique of Brentano's Doctrine of Inner Perception and its Significance for Understanding Husserl's Method in Phenomenology
}

\author{
Cyril McDonnell
}

\begin{abstract}
This article first outlines the importance of Brentano's doctrine of inner perception both to his understanding of the science of psychology in general in his Psychology from an Empirical Standpoint (1874) and to his new science of descriptive psychology in particular which he later advances in his lecture courses on 'Descriptive Psychology' at the University of Vienna in the 1880s and early 1890s. It then examines Husserl's critique of that doctrine in an 'Appendix: Inner and Outer Perception: Physical and Psychical Phenomena', which Husserl added to the 1913 re-issue of his Logical Investigations (1900-01). This article argues that, though Husserl promotes a very different method in phenomenology to the method of 'inner perception' which Brentano designs for descriptive psychology, one cannot fully understand the significance of the method that Husserl advocates in phenomenology, both in the Logical Investigations and in Ideas I (1913), without (1) distinguishing four different meanings for 'inner perception' (as accompanying inner percept, inner reflection, incidental awareness, immanent perception) in Brentano's thought and addressing (2) the problematic issue of the particular kind of scientific method for his new science of descriptive psychology which Brentano bequeaths to Husserl.
\end{abstract}

Franz Brentano (1838-1917) is probably most renowned for his appeal to 'what the Scholastics of the Middle Ages called the intentional (or mental) in-existence of an object' in an effort to describe, in his 1874 publication Psychology from an Empirical Standpoint [PES], the characteristic feature of our human consciousness. ${ }^{1}$ Though Brentano re-introduced this concept for the purposes of removing all confusion and disagreement over what distinguishes the psychical from the physical, much disagreement and confusion, alas, ensued among his commentators and critics regarding what exactly he meant by 'the intentional in-existence of an object', as well as by his later characterization of the directedness of acts of consciousness towards their objects as an 'intentional relation'.

\footnotetext{
${ }^{1}$ Franz Brentano, Psychology from an Empirical Standpoint, trans. by Antos. C. Rancurello, D.B. Terrell \& Linda L. McAlister (London: Routledge \& Kegan Paul, 1973; Routledge, 1995), p. 88 [henceforth, abbreviated as PES]; Psychologie vom empirischen Standpunkt (Leipzig: Duncker and Humblot, 1874), pp. 124-25.

${ }^{2}$ In full the famous 1874 passage reads: 'Every psychical phenomenon is characterised by what the Scholastics of the Middle Ages called the intentional (or mental) inexistence of an object, and what we might call, though not wholly unambiguously, reference to a content, direction towards an object (which is not to be understood here as meaning a thing), or immanent objectivity. Every psychical phenomenon includes something as object within itself, although they do not all do so in the same way. In presentation something is presented, in judgement something is affirmed or denied, in love [something is] loved, in hate [something is] hated, in desire [something is] desired and so on.' (PES, p. 88:124-125.) In this passage, then, Brentano employs no less than 'five typifying expressions' to define psychical act-experiences: every psychical phenomenon is characterised by the (1) 'intentional inexistence of an object', (2) 'mental inexistence of an object', (3) 'immanent objectivity', (4) 'reference to a content', and (5) 'direction towards an object'. Theodore de Boer, The Development of Husserl's Thought, trans. by Theodore Plantinga (The Hague: Martinus Nijhoff, 1978), p. 6.) As de Boer also notes, for Brentano, expressions (1), (2) and (3) are 'fully synonymous' and point to 'the fact that they [psychical act-experiences] include a content', and that '( $T)$ his content is more precisely defined as intentional or immanent or mental' (ibid.). Expressions (4) and (5) are different aspects of psychical act-experiences. They are concerned with the directedness or relation (Richtung, Beziebung) of a psychical act-experience towards a content or an object (ibid.). In the 1874 passage, Brentano understands these expressions to be describing the same thing, namely, the object-relatedness of psychical act-experiences. Thus John Passmore, the historian of philosophy, is correct to note that, in the 1874 passage, Brentano takes 'these phrases [i.e., (4) and (5)] to be synonymous'. J. Passmore, A Hundred Years of Philosophy (London: Duckworth, 1957; Penguin Books, 1968; 1980), p. 178. Sometime after PES, however, Brentano uses the terrn 'intentional' to describe this directedness of psychical-acts to their objects (within consciousness) as an 'intentional relation'. Cf., Franz Brentano, The Origin of our Knowledge of Right and Wrong, trans. by Roderick M. Chisholm \& E. Schnerwind (London and New York: Routledge \& Kegan Paul, 1969), p.14, and his corresponding n. 19, my emphasis; Vom Ursprung sittlicher Erkenntnis (Leipzig: Duncker and Humblot, 1889). (C) Cyril McDonnell, 'Husserl's Critique of Brentano's Doctrine of Inner Perception and its Significance for Understanding Husserl's Method in Phenomenology', in Maynooth Philosophical Papers, Issue 6 (2011), ed. by Amos Edelheit (NUIM: Maynooth, 2012), pp. 74-111
} 
Another factor complicating the understanding of Brentano's doctrine of the 'intentionality' of consciousness is that several of Brentano's students and followers, whilst advocating allegiance to his original concept, promote different versions of 'Brentano's thesis' (as it is often referred to today), and these versions themselves often come into direct conflict not only with Brentano's own doctrine on the intentionality of consciousness but also with each other. ${ }^{3}$ Notwithstanding the disputes regarding the correct interpretation and meaning of 'Brentano's thesis' and the faithfulness or otherwise of the various versions of 'Brentano's thesis' that were subsequently unfurled, Edmund Husserl was in no doubt about both the cogency and the originality of Brentano's discovery of the 'intentionality of consciousness' and the significance of this to his own idea of phenomenology, for, as Husserl reminds us, in his 1931 'Author's Preface to the English Edition' of the First Book of his Ideas: General Introduction to Pure Phenomenology (1913), 'his [Brentano's] conversion (Umwertung) of the scholastic concept of intentionality into a descriptive root-concept of psychology constitutes a great discovery, apart from which phenomenology could not have come into being at all'. ${ }^{4}$

Towards the beginning of his course of lectures on Descriptive Psychology, which Brentano delivered at Vienna University from 1887 to 1891 , Brentano stresses this feature of consciousness to his students, remarking, '(T)he peculiarity which, above all, is generally characteristic of [human] consciousness, is that it shows always and everywhere, i.e. in each of its separable parts, a certain kind of relation, relating a subject to an object. This relation is also referred to as "intentional relation" (intentionale Beriebung)'. Franz Brentano, Descriptive Psychology, trans. and ed. by Benito Müller (London: Routledge, 1995), p. 23; henceforth, abbreviated as DP; Deskriptive Psychologie, ed. by Roderick M. Chisholm \& Wilhelm Baumgartner (Hamburg: Meiner, 1982). Brentano, then, held not one but two theses of intentionality, one concerning the immanence of objects in consciousness and another concerning the directedness of acts in consciousness towards their objects (however the latter may be understood). Herbert Spiegelberg remarks that for Brentano 'the second characterization of the psychic phenomenon, "reference to an object," — - one that Brentano had also spotted in the 1874 passage of PES (p. 88), as Spiegelberg acknowledges — 'is [...] the only permanent one for Brentano' because 'Brentano came to reject during what Brentano scholars call the crisis of immanence ("Immanenzkrise") of 1905 [...] [the] very doctrine of the mental inexistence of the object of knowledge in the soul'. H. Spigelberg, The Phenomenological Movement. A Historical Introduction (The Hague: Nijhoff, 1976), p. 40; 3rd rev. and enlarged edn (Dordrecht: Kluwer, 1994), p. 37, p. 48, n. 19.

3 Cf., Dermot Moran, 'The Inaugural Address: Brentano's Thesis', Proceedings of the Aristotelian Society Supplementary vol. LXX (1996), 1-27. This commentator believes that Brentano's more immediate students (Twardowski and Husserl are named together) interpret 'Brentano's thesis' more faithfully than later analytic commentators who follow R.M. Chisholm's 'influential account' (ibid. p. 2) unfurled in the 1960s. Philip J. Bartok, however, has recently argued that both analytic and phenomenological approaches do not do entire justice to 'Brentano's thesis' in that 'each reads Brentano in terms of philosophical concerns and standards that were not his own'. ('Brentano's Intentionality Thesis: Beyond the Analytic and Phenomenological Readings', Journal of History of Philosophy, vol. 43, no. 4 (2005) pp. 437-60 ( p. 439).) During the time Husserl attended Brentano's lectures in Vienna (1884-1886) Brentano, nonetheless, held not one but two theses of intentionality (see, supra, n. 2), and Husserl develops both of them, and explicitly criticises Twardowksi's concept of intentionality in his study On the Content and Object of Presentations, published twenty years after PES, in 1894. Cf., Husserl, Logical Investigations, trans. by John N. Findlay (London: Routledge \& Kegan Paul, 1970), vol.1, p. 290, n. 1, and vol. 2, pp. 657-8; Logische Untersuchungen. I. Teil: Prolegomena zur reinen Logik (Halle, 1900), II. Teil:Untersuchungen zur Phänomenologie und Theorie der Erkenntnis, In zwei Bänden (Halle, 1901); Gesammelte Werke, Husserliana (Dordrecht: Kluwer), Volume XVIII, ed. by Elmar Holenstein (1975) and Volume XIX, ed. by Ursula Panzer (1984). When addressing 'Brentano's Thesis', therefore, it is of importance to be sure about whose thesis and which thesis of intentionality that is the target of either interpretive elucidation or critical evaluation.

${ }^{4}$ Edmund Husserl, 'Author's Preface to the English Edition' of Ideas: General Introduction to Pure Phenomenology, trans. by W.R. Boyce Gibson (London: Unwin \& Allen, 1931), pp. 5-22 (pp. 16-17). According to Husserl, '(I)ntentionality is the name (der Tite) of the problem encompassed by the whole of phenomenology. The name precisely expresses the fundamental property of consciousness'. Ideas Pertaining to a Pure Phenomenology and to a Phenomenological Philosophy, First Book, General Introduction to a Pure Phenomenology, trans. by Fred Kersten (The Hague: Martinus Nijhoff Publishers, 1982), p. 349:303. Ideen zu einer reinen Phänomenologie und phänomenologischen Philosophie, Erstes Buch, Allgemeine Einführung in die reine Phänomenologie (Halle: Niemeyer, 1913); Husserliana Vol. III/ 1 \& III/ 2 ed. by Karl Schumann $(1977,1995)$. Further references will be made to Fred Kersten's English translation and abbreviated, henceforth, as Ideas I, with English pagination followed by German pagination, separated by a colon. 
Understandably, therefore, significant attention has fallen on Husserl's development of Brentano's doctrine of intentionality as a means of trying to approach Husserl's idea of phenomenology as a science of consciousness and its objectivities. ${ }^{5}$ Considerably less attention, however, has fallen on Brentano's doctrine of inner perception' (die innere Wabrnebmung), which is the 'method' that Brentano claims to have used in his discovery of the 'intentionality' of consciousness and upon which his new science of 'descriptive psychology' is based. ${ }^{6}$ Elsewhere, I have dealt with Brentano's modification of the scholastic concept of intentionality into a root-concept of descriptive psychology and assessed some of the implications this has for understanding Husserl's

\footnotetext{
5 There are many interpretations of Husserl's concept of intentionality but De Boer's extensive and meticulous study The Development of Husserls Thought, which traces the unfolding of the theme of intentionality from its first occurrence in Husserl's earliest writings, though his Logical Investigations (1900-01), up to and including Husserl's turn to transcendental idealism in Ideas I (1913), is still one of the best accounts of this topic. For a shorter account, see, Klaus Hedwig, 'La discussion sur l'origine de l'intentionalité husserlienne', Les Etudes Philosophiques (1978), 259-72, and his 'Intention: Outlines for a History of a Phenomenological Concept', Philosophy and Phenomenological Research, vol. 39 (1979), 326-40. Dermot Moran thinks that 'Husserl's own breakthrough insight concerning intentionality came in 1898 (as he later recalled in Krisis) when he realised there was a "universal a priori correlation between experienced object and manners of givenness". In other words, that intentionality really encapsulated the entire set of relations between subjectivity and every form of objectivity'. Edmund Husserl: Founder of Phenomenology (Cambridge: Polity, 2005), pp. 18-19. Husserl, nonetheless, credits Brentano with the initial revaluation (Umwertung) of the Scholastic theory of the objectrelatedness of acts of the will ('intentio, sicut ipsum nomen sonat, significat in aliquid tendere [...] intentio proprie est actus voluntatis', S.Th. 1a 2ae q.12 a.1) into a root-concept of descriptive psychology denoting the object-relatedness of all psychical act-experiences, but credits himself, in the development of his own idea of phenomenology, with the working out of the implications of such 'correlativity', though Brentano did not see this. See, Edmund Husserl, Phänomenologische Psychologie, Vorlesungen Sommersemester 1925, Gesammelte Werke, Husserliana (Dordrecht: Kluwer, 1968), Vol. IX, ed. by Walter Biemel, ‘g 3 d Brentano als Wegbereiter für die Forschung in innerer Erfahrung - Enkdeckung der Intentionalität als Grundcharakter des Psychischen', pp. 31-5; Phenomenological Psychology. Lectures, Summer Semester 1925, trans. by John Scanlon (The Hague: Martinus Nijhoff, 1977), 'Section (d) Brentano as pioneer [path finder] for research in internal experience - discovery of intentionality as the fundamental character of the psychic', pp. 23-27. The first thesis that Brentano uses in the 1874 passage of $P E S$, regarding the 'intentional in-existence of an object', is used to mark its opposition to real extra-mental existence. This concept of 'intentio' as the abstracted form or intelligible species residing intentionally (and not really) in the soul of the knower is an entirely different concept to 'intentio' when deployed in Scholastic theory of the will. Cf., H.D. Simonin, 'La Notion d'intentio dans l'oeuvre de S. Thomas d'Aquin', Revue des Sciences philosophiques et théologiques, 19 (1930), 445-63. St Thomas, as Simonin notes, never confuses the two different meanings of the one and same term ('un seul et même terme') of intentio, when the latter is employed in either the cognitive or conative order (p. 451). The Scholastic metaphysical doctrine and distinction between intentional as mind-dependent existence and esse naturale (real extra-mental existence) that Brentano appeals to his PES 1874 passage is still operative, nevertheless, in Husserl's Ideas I (1913), when he describes the world, after his famous world-annihilation thought-experiment, as only an intentional correlate (mind-dependent object) of consciousness. See, Ideas I, \$49 'Absolute Consciousness and the Residuum After the Annihilation of the World'.

${ }^{6}$ See, Brentano, PES, Book I, Psychology as a Science, Chapter 2 'Psychological Method with Special Reference to its Experiential Basis', (\} 2 \text { 'Über die Methode der Psychologie, insbesondere die Erfahrung, } welche für sie die Grundlage bildet'), pp. 40-4. Shortly after the publication of PES, Brentano begins to separate the task of describing clearly the contents of consciousness and its objectivities ('descriptive psychology') from the task of explaining the causal origins of such phenomena in human consciousness ('genetic psychology'), and advocates the natural scientific approach and methodology for the latter part of the science of empirical psychology. In the 1880s Brentano even coined the term 'Psychognosie' for the descriptive part of the science of empirical psychology and the term 'psychognost' for the descriptive psychologist. He borrowed the idea of dividing the science of empirical psychology into two component parts, a descriptive and a genetic part, from a model that occurred in other natural sciences. 'In the same way as orognosy and geognosy precede geology in the field of mineralogy, and anatomy generally precedes physiology in the more closely related field of the human organism, psychognosy [descriptive psychology] [...] must be positioned prior to genetic psychology'. See, DP, Ch. 1 'Psychognosy and Genetic Psychology', pp. 3-11 (p. 8). In relation to the natural science of psychology, descriptive psychology, then, as Brentano defines it, is essentially preparatory in nature in that its main aim is to describe clearly what the genetic, naturalscientific part would later endeavour to explain causally using the method, results and theories of natural science. Cf., also, Brentano's letter to Oskar Kraus in 1894, published in the Appendix of PES, pp. 369-70.
} 
philosophy. ${ }^{7}$ In this article, I wish to draw attention to Husserl's critique of Brentano's doctrine of inner perception and assess some of the main implications this has for understanding Husserl's 'method' of 'doing' phenomenology. As is well known, Husserl believed that the method that he fought hard to wrest from 'the things themselves' (die Sachen selbst) was of pivotal importance to his elaboration of what constitutes a proper concept of phenomenology. As is equally well known, however, this method of philosophizing was either modified substantially by many of Husserl's so-called 'followers' or rejected outright by other 'followers' who proposed alternative methods to Husserl's method for philosophy and phenomenological research. ${ }^{8}$ It is, nonetheless, arguably the case that it was Brentano's rejection of Husserl's method of doing philosophy that disappointed Husserl most, but this did not quell Husserl's insistence to his own students in his 1925 Summer Semester lecture-course that what he attempted to do was to advance Brentano's ideas, even if 'Brentano himself did not recognise it as the fruition of his own ideas'. ' This is not to say that Husserl develops a very different method to Brentano, for, as we shall see, he does, but over-identifying Husserl's method with Brentano's method, or ignoring the relation between Husserl's method and Brentano's are both to be avoided in coming to understand Husserl's method in philosophy and phenomenological research.

In the first section of this article, I will outline the main features of Brentano's doctrine of inner perception that are of most relevance to an evaluation of his views on psychology in general in PES and of his new science of descriptive psychology in particular which he subsequently developed in his lectures on Descriptive Psychology $[D P]$ at the

\footnotetext{
${ }^{7}$ See, Cyril McDonnell, 'Brentano's Revaluation of the Scholastic Concept of Intentionality into a RootConcept of Descriptive Psychology', in Yearbook of the Irish Philosophical Society (Dublin: Irish Philosophical Society, 2006), ed. by Catherine Kavanagh, pp. 124-171.

${ }^{8}$ Heidegger is probably the most well-known figure to have claimed not only to have followed Husserl's method in philosophy of ' $z u$ den Sachen Selbst', but do to so even 'more pointedly' (sachgerechteren Festhaltens) than Husserl himself did, cf., William Richardson, Heidegger: Through Phenomenology to Thought (Hague: Nijhoff, 1963), pp. ix-xxiii (p. xv), but Husserl, who did believe in the 1920s that Heidegger was a faithful adherer of his method, after undertaking a serious study of Heidegger's Being and Time I (1927) (and other recent publications by Heidegger) in 1930-31, came to 'the distressing conclusion' that, 'philosophically I have nothing to do with this Heideggerean profundity, with this brilliant unscientific genius; that Heidegger's criticism [of my work], both open and veiled, is based upon a gross misunderstanding [of my work]; that he may be involved in the formation of a philosophical system of the kind which I have always considered my life's work to make forever impossible. Everyone except me has realised this for a long time.' Edmund Husserl, 'Letter to Alexander Pfänder, January 6, 1931', in Edmund Husserl, Psychological and Transcendental Phenomenology and the Confrontation with Heidegger (1927-1931): The 'Encyclopaedia Britannica' Article, The Amsterdam Lectures, "Phenomenology and Anthropology" and Husserl's Marginal Notes in 'Being and Time' and 'Kant and the Problem of Metaphysics', trans. and ed. by Thomas Sheehan \& Richard E. Palmer (Dordrecht: Kluwer Academic Press, 1997), p. 482. That Heidegger developed Husserl's ideas very differently, of course, does not imply that he misunderstood Husserl's work, but Heidegger does not subscribe to Husserl's 'method' in phenomenology and phenomenological research. The subsequent dispute, then, between the so-called early realist 'followers' of Husserl's 'eidetic method' (Göttingen School) and the later 'followers' of Husserl's 'transcendental method' (Freiburg School) - both of whom accused each other of not understanding 'the Master's intentions' properly - deflects attention from Husserl's own insistence and consistent re-iteration that what he attempted to do was to advance the method that Brentano had deployed in his lectures on 'descriptive psychology' at Vienna University, which Husserl attended from 1884 to 1886. For the impact that these lectures had on Husserl's decision to continue on with a career in mathematics (for he had already completed his $\mathrm{PhD}$ in Mathematics) or to devote his life to philosophy, see Husserl's own account, written shortly after Brentano's death in 1917, 'Reminiscences of Franz Brentano', in The Philosophy of Brentano, ed. by Linda L. McAlister (London: Duckworth, 1976), pp. 47-55.

${ }^{9}$ Husserl, Phenomenological Psychology, p. 28. Brentano thought that Husserl's descriptive-eidetic psychology had not advanced his idea of descriptive psychology, that his doctrine of the intuition of essences was a spurious doctrine, and that Husserl had wrongly accused him of psychologism. Cf., Brentano, PES, 'Appendix (1911), Supplementary Remarks, IX ‘On Genuine and Fictitious Objects', pp. 291-301; XI 'On Psychologism’, pp. 306-7. This philosophical dispute between Brentano and Husserl is still on-going among commentators. Cf., Robin D. Rollinger, 'Brentano and Husserl' in The Cambridge Guide to Brentano, ed. by Dale Jacquette (Cambridge: Cambridge University Press, 2004), pp. 255-76.
} 
University of Vienna in the 1880s-1890s. ${ }^{10}$ In the second section of this article, I will examine Husserl's critique of Brentano's doctrine of inner perception in an 'Appendix' that Husserl wrote and published for the 1913 re-issue of his Logical Investigations (1900-01) and that he entitled 'Outer and Inner Perception: Physical and Psychical Phenomena'. ${ }^{11}$ In this 'Appendix', Husserl outlines Brentano's account in PES and then distinguishes 'what is indubitably significant in Brentano's thought-motivation from what is erroneous in its elaboration'. ${ }^{12}$ Here is one place where we can witness major points of philosophical agreement and disagreement between Husserl and Brentano's thought (and commentators, critics and historians of Husserl's thought could do well to examine this 'Appendix'). More importantly, however, here is a place where we can see, quite clearly, the way in which Husserl endeavours not only to correct 'defective phenomenological analysis' that Brentano supplies but also to hold fast and more pointedly, than Brentano himself did, to the task of addressing the things of concern (die Sachen selbst), namely, in this instance, in PES, the descriptive-psychological methodological task of clarifying what we mean when we talk about what is physical and what is psychical. ${ }^{13}$

Assessing the philosophical relationship between Brentano's method of 'inner perception' and Husserl's 'method' of 'doing' phenomenology, however, is made difficult by the fact that Husserl, both in his Logical Investigations (1900-01) and in Ideas I (1913) advances some essential features of a method which Brentano, in his elaboration of his new science of descriptive psychology, either simply does not entertain or explicitly rejects. Thus it will be of importance to include, in section two, a discussion of some central concepts and distinctions that Husserl makes in his analysis of consciousness that are of

\footnotetext{
10 The first time that Brentano delivered a lecture-course entitled 'Descriptive Psychology' was in 1887-88, and he repeated these, without major revision, in 1888-89 and 1890-91. The 1888-89 lecture-course was entitled: 'Deskriptive Psychologie oder bescreibende Phänomenologie', 'Descriptive Psychology or Describing Phenomenology'. See, Spiegelberg, The Phenomenological Movement (1994), p. 27. Thus Husserl, who had attended Brentano's lectures in Vienna University from 1884 to 1886, would not have attended these lectures. Müller, however, informs us that '(E)ven though Husserl left Vienna by the time the present lectures were read by Brentano, he was in possession of a transcript (by Dr Hans Schmidkunz) of the 1887/8 lectures which is kept in the Husserl Archive in Leuven, (call number Q10).' (Introduction, Part I, Descriptive Psychology, p. xiii, n. 14.) Moran also notes that after Husserl left Vienna in 1886 he still 'diligently collected Brentano's lecture transcripts, e.g. his Descriptive Psychology lectures of 1887-91, his investigations of the senses, as well as his studies of fantasy, memory and judgement' (Edmund Husserl: Founder of Phenomenology, pp. 18-19). Brentano, of course, was working on these issues when Husserl attended his lectures because Husserl remarks that one lecture course he took with Brentano was called 'Selected Psychological and Aesthetic Questions [...] [which] was devoted mainly to fundamental descriptive analyses of the nature of the imagination' ('Reminiscences of Franz Brentano', p. 47). Again, another course Husserl took with Brentano, 'Elementary Logic and its Needed Reform', 'dealt with systematically connected basic elements of a descriptive psychology of the intellect, without neglecting, however, the parallel elements in the sphere of the emotions, to which a separate chapter was devoted' (ibid.). 'It was', Husserl informs us, 'from his [these] lectures that I first acquired the conviction that gave me the courage to choose philosophy as my life's work' (p. 47-48). It was, then, the way in which Brentano was attempting to clarify the meaning of concepts employed in the normative sciences of Logic, Ethics and Aesthetics, through the application of his descriptive-psychological method of inquiry, that caught Husserl's attention most. In Brentano's earlier PES (1874) the task of descriptive psychology was to clarify basic concepts for the science of empirical psychology, but sometime after this, Brentano believed that this 'descriptive method' could be used and applied to the problem of the founding of the norms in the disciplines of Logic, Ethics and Aesthetics. For a lucid account of the impact which this development by Brentano of his descriptive method in this direction had on Husserl's initiation in philosophy, as well as on the tasks that Husserl later sought to address in his career in philosophy, see Theodore De Boer's excellent, short article, 'The Descriptive Method of Franz Brentano: Its Two Functions and Their Significance for Phenomenology', in The Philosophy of Brentano, ed. McAlister, pp. 101-7.

${ }^{11}$ Hua Vol. XIX/2, Beilage, ‘Äußere und innere Wahrnehmung. Physische und psychische Phänomene’, pp. 751-775 (1913 edition). 'Appendix: External and Internal Perception: Physical and Psychical Phenomena', in Husserl, Logical Investigations, pp. 852-869.

${ }^{12}$ Husserl, ‘Appendix', esp., \\2-3 (pp. 856-859).

13 Ibid., p. 859, and see, esp., $₫ 4$, pp. 859-860.
} 
pivotal importance both to his development of his 'method' in phenomenology and to his relinquishing of Brentano's method of 'inner perception'. The conclusion then provides some evaluations of the significance of this 'Auseinandersetzung' between Brentano and Husserl on the question of method in 'descriptive psychology' for understanding Husserl's 'scientific' method in phenomenology and his idea of phenomenology in general.

\section{I}

\section{BRENTANO's DOCTRINE OF INNER PERCEPTION}

In PES, Brentano draws attention to what he believes is the experiential origin of the science of psychology, remarking,

Psychology, like all natural sciences, has its basis in perception (Wabrnehmung) and experience (Erfahrung). Above all, however, its source is to be found in the innerperception of our own psychical phenomena (der eigenen psychischen Pbänomene). We would never know what a thought is, or a judgement, pleasure or pain, desires or aversions, hopes or fears, courage or despair, decisions and voluntary intentions if we did not learn what they are through inner perception of our own phenomena. Note, however, that we said that innerperception (innere Wabrnebmung) and not introspection, i.e. inner observation (innere $B e o b a c b t u n g$ ), constitutes this primary (erste) and indispensable source (unentbebrliche Quelle) of psychology. ${ }^{14}$

The origin that Brentano is clearly interested in above, then, is how we come to know or learn about our own experiences directly, rather than knowledge that comes from any hypothetical theorizing about their causes. In this regard, his approach to this topic is quite similar to David Hume's, who, in his Treatise of Human Nature, is likewise more interested in the cognitional, not causal origins of our own experiences. ${ }^{15}$ What natural scientists study and arrive at through their observations, scientific hypotheses and experimental technique is simply not knowledge that we arrive at through inner perception of our own psychical phenomena'. ${ }^{16}$ This is why the appeal to the 'inner perception of our own psychical phenomena' does not figure centrally in the method of the natural science of psychology; natural scientists, rather, appeal to, as mentioned above, a method that involves observation, scientific hypotheses and experiment, such as promoted, for instance, by Wilhelm Wundt, in his seminal study Principles of Physiological Psychology, also published in

\footnotetext{
${ }^{14}$ Brentano, PES, Book I, Psychology as a Science, Chapter 2 'Psychological Method with Special Reference to its Experiential Basis', ( $\int 2$ 'Über die Methode der Psychologie, insbesondere die Erfahrung, welche für sie die Grundlage bildet'), pp. 40-4, English trans. mod.

${ }^{15}$ For a lucid account of Hume's way of addressing 'the chief argument' of his Treatise, his theory of causation, see, Matthew O’Donnell, 'Hume’s Approach to Causation', Philosophical Studies, 10 (1960), 64-99 (p. 66). Though trained earlier in Scholastic philosophy Brentano, by the time he wrote PES, had become thoroughly acquainted with Hume's Treatise and refers to it on several key points in PES. One of the chief characteristics of Brentano's thinking, as Husserl remarks, is that it 'never stood still' ('Reminiscences of Franz Brentano', p. 50). This explains the many reputations that followed Brentano, some of which were far from complementary. Husserl, for instance, recalls that when he arrived at Vienna University in 1884, he went to Brentano's lectures 'at first merely out of curiosity, to hear the man who was the subject of so much talk in Vienna at that time, but whom others (and not so very few) derided as a Jesuit in disguise, as a rhetoritician [viz], a fraud, a Sophist, and a Scholastic' (ibid., p. 47). Husserl, however, tells us that he was 'soon fascinated and then overcome by the unique clarity and dialectical acuity of his explanations, by the so to speak cataleptic power of his development of problems and theories' (ibid., p. 48). And '(M)ost impressive was his effectiveness in those unforgettable philosophy seminars. (I remember the following topics: Hume's Enquiry Concerning Human Understanding, and Enquiry Concerning the Principles of Morals; Helmholtz's lecture Die Tatsachen der Warhnehmung (The Facts of Perception); and Du Bois-Reymond's Über die Grenzen des naturerkennens (On the Limits of the Knowledge of Nature)' (ibid.).

16 This is 'because', as O'Donnell points out, 'Hume's "first maxim" is that in the end we must rest content with experience [T/60/b]' (p. 65, n. 11). Brentano follows suit in PES. 'My psychological standpoint is empirical; experience alone is my teacher', 'Foreword to the 1874 Edition' (PES, p. xxxii).
} 
1874, the same year as Brentano's PES. ${ }^{17}$ In emphasizing, then, that the origin of our knowledge of 'psychical phenomena' relies upon 'inner perception', and not on any form of inner or outer (sense) observation, Brentano is clearly not following the line and method advocated by the natural science of psychology. Indeed, sometime after the publication of $P E S$, Brentano, in his lectures on DP at Vienna University, makes a clear distinction between what he calls 'genetic psychology', which relies on causal analysis and naturalscientific theories, and 'descriptive psychology' or 'describing phenomenology', which relies solely and exclusively on the evidence of inner perception. ${ }^{18}$ Why Brentano attributes such methodological significance to 'inner perception' for the science of psychology in general, as he understands it in PES, needs to be determined first, nontheless, before assessing his views on 'inner perception' and what 'empirical standpoint' in psychology he is exactly referring to in his title of PES.

\section{(i) The Significance and Priority of Inner Perception in Brentano's Understanding of the Science of Psychology in PES}

PES comprises two books: Book I 'Psychology As a Science' and Book II 'Psychical Phenomena in General'. ${ }^{19}$ In Book I, Brentano begins by drawing attention to the etymology of the Greek term, '(T)he word "psychology" means science of the soup, and proceeds to credit Aristotle with the inauguration of psychology as a science, noting, 'Aristotle, who was the first to make a classification of science and to expound its separate branches in separate essays, entitled one of his works Peri Psyches. ${ }^{20}$ By the soul, Aristotle, Brentano informs his reader, means 'the form, the first activity, the first actuality of a living being. And he considers something a living being if it nourishes itself, grows and reproduces and is endowed with the faculties of sensation and thought, or if it possesses at least one of these faculties'. ${ }^{21}$ Thus 'the oldest work on psychology', Brentano continues, 'goes on to discuss the most general characteristics of beings endowed with vegetative as well as sensory or intellectual faculties'. ${ }^{22}$ No sooner, however, does Brentano draw attention to this original demarcation of the field of enquiry for psychology by Aristotle as a science of living beings (plants, animals and human beings), than he remarks that, with the emergence of various natural sciences, many of the areas that were initially associated with this view of psychology are now no longer considered to be the preserve of the science of psychology. Botany, for example, has emerged and investigates vegetative life activity, and other natural sciences, such as, zoology, biology, anatomy and physiology examine various dimensions of animal-sense life activity, so much so, 'that their investigation [into the sensitive soul of the human being] became the province of the physiologist rather than the psychologist. ${ }^{23}$ Also, some of the salient features of human conscious, intellectual-life activity, such as our experience of colours, odours and sounds, as well as our brain

\footnotetext{
${ }^{17}$ Brentano knew and quotes this study on several occasions in PES (see, p. 6), and the work of several other natural scientists or philosophers interested in natural scientific endeavours (e.g., Fechner, Maudsley, Bain, Condillac, Helmholtz, Horwicz, Darwin, Lavoisier, the Mills).

${ }^{18}$ See, supra, n. 6 and n. 10.

19 Originally, Brentano had planned six books for PES ('Foreword to the 1874 Edition', ibid., p. xxvii-xxix) but only completed and published the first two. The final book was to deal with the relation between the mind and the body, culminating in addressing the question of immorality (Book VI). Once the descriptivepsychological task in Book II of distinguishing 'physical' and 'psychical phenomena' seemed to be accomplished by Brentano (at least to his own satisfaction), he realized that his method of descriptive psychology could be employed in addressing problems regarding the foundations of the normative sciences of logic, ethics and aesthetics. Thus, in the Foreword to his next publication The Origin of our Knowledge of Right and Wrong (1889), he refers to his 'new lines of thinking' (in the direction of the founding of the normative disciplines) for his science of descriptive psychology. See, De Boer, 'The Descriptive Method of Franz Brentano: Its Two Functions and Their Significance for Phenomenology'.

${ }^{20}$ PES, p. 4.

${ }^{21}$ Ibid.

22 Ibid.

${ }^{23}$ Ibid.
} 
functions and brain activity, now come under the scrutiny of natural-scientific theories of stimuli and effect, and so forth. ${ }^{24}$

Given Brentano's earlier background in philosophy — prior to the publication of PES in 1874, he had already completed and published two highly acclaimed works on Aristotle, his doctoral study On the Several Senses of Being in Aristotle (1862) and his 1866 habilitation thesis The Psychology of Aristotle, in Particular His Doctrine of the Active Intellect (1887) - one would expect that Brentano would disapprove of this excision of reflections on plant-life activity and animal-sense life activity from the 'modern definition' of psychology, but he does not; in fact, he approves of it, concluding, '( $T$ )his narrowing down of the domain of psychology was not an arbitrary one. On the contrary, it appears to be an obvious correction necessitated by the nature of the subject matter itself ${ }^{25}$ Whether this is a correction necessitated by the subject-matter itself, however, depends on one's view of the subject-matter of psychology as a science, and by 1874 Brentano clearly believes that psychology no longer could be defined in the traditional manner as a science of the soul (of living beings) but exclusively as the science of 'our own psychical phenomena in general'. This is a significant turning point in his understanding of psychology as a science. It is of importance to understand why Brentano makes such a move. ${ }^{26}$

There are two distinct, but related reasons why Brentano approves of this narrowing down of the domain of psychology as a science. Firstly, the rise of the various natural sciences (botany, biology, zoology, physiology etc.) simply cannot be ignored; so, if psychology, as a science, is to continue as a particular science within the various natural sciences, then it too will have to define and secure for itself, in some manner of speaking, its own subject-matter. Secondly, Brentano thinks that the ability of a human being to reflect upon its own 'phenomena' or 'activity' ('psychical phenomena') can provide just such an 'experiential basis' and 'domain' of enquiry for the newly emergent science of empirical psychology. This is why he likes to insist on the point that though '(P)sychology, like all natural sciences, has its basis in perception and experience, [...] its primary and indispensable source [...] [is to be found in] the inner perception of our own psychical phenomena'. ${ }^{27}$ In this manner, Brentano is convinced that 'inner perception of our own psychical phenomena' can and does secure an 'empirical' area of investigation for the newly emergent natural science of psychology. What is at stake here, then, is the continued existence of psychology as a science and the precise place for the science of psychology within the evolution of the natural sciences. Brentano, nevertheless, does regard psychology as 'the crowning pinnacle' of the natural sciences and as one that promises itself to be 'the science of the future', influencing aesthetics, educational pedagogy, logic, moral, political and social science. ${ }^{28}$ Thus Brentano is hopeful that, just as physics has matured and established itself as the natural science of 'pure physical phenomena', so too,

\footnotetext{
24 Ibid.

${ }^{25}$ Ibid.

${ }^{26}$ Brentano, who likes to credit Aristotle with many of the doctrines that he espouses, says that Aristotle himself hints at this in Bk III of De Anima when he says that reflections on organs are 'not the proper province of one who studies the soul [and its operations], but of one who studies the body' (PES, p. 5); clearly, however, Brentano has jettisoned philosophically his allegiance to any Aristotelian approach to psychology, and embraced the 'modern definition' of psychology, inaugurated by Descartes and continued by Locke and Hume, in affirming the 'mind' and the immediate access to 'our own psychical phenomena' as the primary and main object of enquiry for psychology.

27 PES, pp. 40-4. That this basis of 'inner perception' later becomes a dispensable source (eine entbehrliche Quelle) in Husserl's elaboration of the intuition of essences in the Logical Investigations (1900-01) was, therefore, entirely incomprehensible to Brentano. See, however, Bartok, 'Brentano's Intentionality Thesis', and Brentano's (my emphasis) restriction of the term 'phenomena (Phänomene)' to 'immediate experiential facts (Erfahrungstatsachen)', p. 442.

${ }^{28}$ PES, p. 3, 25.
} 
psychology, this fledgling natural science, can arise and succeed to establish itself as the natural science of pure 'psychical phenomena in general'. ${ }^{29}$

In maintaining that psychology finds its origins in the inner perception of our own phenomena', nevertheless, Brentano has, in effect, switched his entire philosophical allegiance away from any Aristotelian understanding of psychology as a science of the soul, and adopted the more 'modern conception' of philosophical psychology accredited to Descartes, wherein the first and primary reality for investigation is the mind and not living beings given to outer perceptual-sense experience (however the latter are to be subsequently explored, either in the way Aristotle did, through observation and critical metaphysical speculation, or in the way contemporary natural science does through observation, scientific hypotheses and laboratory experimentation). At any rate, Brentano believes that the way in which consciousness can, in the light of its own evidence, know itself by reflecting directly on its own contents is a path that is available to psychology as a science to pursue. ${ }^{30}$ Nowhere in his PES, or in his lectures on DP in the 1880 s and 1890s, does Brentano relinquish this Cartesian-Lockean-Humean conviction regarding the manner in which consciousness can gain knowledge of itself from reflection within itself. ${ }^{31}$ Indeed, in a 'Supplement' that he prepared for the 1911 re-issue of his PES Brentano re-iterates and emphasizes this precise approach, asserting: ' $(T)$ he fact that the mentally active subject has himself as object of a secondary reference regardless of what else he refers to as his primary object, is of great importance'. This fact is of great importance to Brentano in his conception of psychology as a science in PES precisely because it is on this basis that he believes that a correction and a refinement to the traditional Aristotelian subject-matter of psychology, away from being a science of the soul and towards being a science of psychical phenomena, must be made by the subject-matter itself. Without the ability of consciousness to reflect upon its own contents, and the desire of the scientist to do so, there would be, in Brentano's estimation, no impetus or 'province' for a natural science of psychical phenomena in general to investigate. ${ }^{33}$ Furthermore, since 'inner perception' can also double-up, as it were, to serve as a particular 'method' of investigation for the science of psychology, or, at least, more accurately speaking, for the descriptive part of the science of

\footnotetext{
${ }^{29}$ See, PES, pp. 98-100, and his comments, however, on the 'tacit limitations' that both of these definitions of physics as the science of physical phenomena and psychology as a science of psychical phenomena include. 30 John Locke famously held that all our knowledge came from the twin founts of sensation and reflection. Cf. J. Locke, An Essay Concerning Human Understanding, ed. R. Woolhouse (London: Penguin, 1997), Book II, ch 1. One of the meanings that Brentano has for 'inner perception' is just this 'method' of reflecting on consciousness. Hume follows suit, 'Impressions may be divided into two kinds: those of sensation, and those of reflection'. Treatise, Bk $1 \mathrm{Pt}$ 1, Sec. 2 Para 1. About his distinction between impressions that are based upon and derived from sensations and ideas that one derives from reflecting upon one's own mental activities, Hume remarks: 'The examination of our sensations belong more to the anatomists and natural philosophers than to moral [human science]. [...] For this reason, I have here [in the Treatise] chosen to begin with ideas [of reflection]' (ibid.). Before Hume and Locke, however, Aquinas did remark on our knowledge of our self/ mind: 'Our mind knows itself not by its own substance but by its activities - and through a consideration of those activities man can come to a general understanding of the mind's nature — but that requires diligent and subtle investigation' (S.Th. 1a. q. 87. a.1). Brentano, nonetheless, follows Locke and Hume, and not Aquinas and Aristotle in PES.

31 By 1874 Brentano had clearly moved away from his originally held Aristotelian view of psychology as a science and concurs with the 'modern definition' of psychology, as instituted and developed by Descartes, Locke, and Hume, but his reputation as a Scholastic still surrounded him in his Vienna period (1874-1894). See, Husserl, 'Reminiscences of Franz Brentano', quoted supra, in n.15. Cf., also, Rolf George, 'Brentano's Relation to Aristotle', in Die Philosophie Franz Brentanos, ed. by Roderick M. Chisholm \& Rudolf Haller (Amsterdam: Rodopi, 1978), pp. 249-266.

32 PES, Supplement, pp. 276-77.

${ }^{33}$ In doing this, Brentano is quite aware that he is aligning his conception of psychology to the "modern conception' of psychology, and not to any Aristotelian conception of psychology. This marks a significant break from the general views he held in his 1866 habiliation thesis on The Psychology of Aristotle, In Particular his Doctrine of the Active Intellect, published in 1867.
} 
psychology, both a definite method and a particular subject-matter for a new science of descriptive psychology is possible on the very basis of 'inner perception'.

That there is, then, a connection between our natural consciousness and the natural science of consciousness, Brentano is in no doubt - he draws attention, approvingly, to 'the noteworthy trend which is now bringing philosophy and the natural sciences closer together' $-{ }^{34}$ but Brentano is keenly aware that what a natural scientist investigates and discovers (e.g. stimuli and effects, brain functions and its activity etc.) is not directly experienced at all by our natural consciousness in inner perception. In this regard, Brentano acknowledges, at least implicitly, that an important dimension of our natural consciousness simply evades natural-scientific treatment, rather than being contained within any overarching, theoretical, natural-scientific examination of human consciousness itself, but Brentano (for reasons we will see below) does not view this relation between our experience of consciousness and the natural-scientific study of the human being as problematic in his thought. ${ }^{35}$ How descriptive psychology is related to genetic psychology is not addressed, but it is precisely with the experience of the contents of human consciousness, as provided though 'inner perception', that the descriptive part of the science of psychology, as opposed to the natural-scientific 'genetic' part of the science of psychology, is primarily founded and constituted.

There are, then, 'tacit limitations' to what a natural-scientific explanation of human consciousness can provide, "tacit limitations" [nonetheless] which Brentano himself, as Husserl notes, 'expounded [in PES] with characteristic clarity and acuteness'. ${ }^{36}$ The first of the 'limiting conditions' that Brentano identifies is that 'the definition of the natural sciences [as the sciences of physical phenomena ...] do not deal with all physical phenomena, but only with those that appear in sensation, and as such do not take into account the phenomena of imagination'. ${ }^{37}$ 'And even in regard to the former [= sensations]', Brentano adds, 'they [natural sciences] only determine their laws insofar as they depend upon physical stimulation of the sense-organs'. ${ }^{38}$ Thus Brentano concludes,

We could express the scientific task of the natural sciences by saying something to the effect that they are those sciences which seek to explain the sequence of physical phenomena connected with normal and pure sensation (that is, sensations which are not influenced by special psychical conditions and processes) on the basis of the assumption of a world which resembles one which has three dimensional extension in space and flows in one direction in time, and which influences our sense organs. Without explaining the absolute nature (Beschaffenheit) of this world, these sciences would limit themselves to ascribing to its forces capable of producing sensations and of exerting a reciprocal influence upon on another, and determining for these forces the laws of co-existence and succession. Through these laws they would then establish indirectly the laws of sequence of the physical phenomena of sensations, if, through scientific abstraction from concomitant mental conditions, we admit that they manifest themselves in a pure state and as occurring in relation to a constant sensory capacity. We must interpret the expression 'science of physical phenomena' in this somewhat complicated way if it is to be equated with the meaning of natural science. ${ }^{39}$

What Brentano identifies above is what Husserl later, in Ideas I, succinctly calls and sketches as the theoretical attitude adopted by the natural scientist from within 'the general thesis' or 'natural thesis' of 'the natural attitude'. ${ }^{40}$ It is important to note this link that Husserl elaborates upon in Ideas I between the 'general thesis of the natural attitude' and the

\footnotetext{
34 PES, p. 11.

${ }^{35}$ Husserl did take this problematic seriously and attempted to address the relationship between 'descriptive psychology' (philosophy) and natural sciences in the development of his own thought. See, infra, n. 75.

${ }^{36}$ Husserl, 'Appendix', p. 858, n.2.

37 PES, p. 98 (and quoted by Husserl, 'Appendix', p. 858).

${ }^{38}$ Ibid.

${ }^{39}$ PES, pp. 98-9:127-8, trans. slightly mod.; and quoted by Husserl, 'Appendix', p. 856-857.

${ }^{40}$ Husserl, Ideas I, p.51:48.
} 
theoretical position adopted by the natural scientist from within that 'natural attitude', that is, 'the natural scientific attitude'. In the 'general thesis' of the 'natural attitude' (natürliche Einstellung), in perception things are simply there (vorbanden), whether attention is directed towards them or not. In the theoretical position adopted by the natural scientist there is a further step that excludes the particularity of one's own immediate experiences; that is to say, the natural scientist begins of course his study with the experiences of physical phenomena as given to us through sense organs and takes such things as simply there, lying-in-stock and available for analysis (from within the thesis of the natural attitude), but the particularity of one's actual experiences of things given to our outer perceptual-sense experiences is not entertained directly in that science; the natural scientist, rather, assumes that (1) the world has an absolute character, that is to say, it has an essential meaning and an existence that is independent of one's own actual experiencing of the world; that (2) the human being is a being in that world with an invariant sensibility; and (3) that the human being is comparable to any other thing or living being in the world amenable to naturalscientific analysis. From within these limitations and assumptions, discoveries in natural sciences (e.g., Pavlov's salivating dogs, or B.F. Skinner's rat-box experiments, etc.) are attributable univocally to human beings as well as to animals - no more, no less. This is why the natural scientist must abstract from 'concomitant psychical conditions' in their very approach to scientific explanation and interpretation of 'physical phenomena' in order to engage in natural science. ${ }^{41}$ It is, nonetheless, the very 'fact' that we can reflect directly upon the contents of our own consciousness (even more so than the rise of the various natural sciences, or the theoretical position adopted by the natural scientist from within the natural attitude) that leads Brentano to the central contention in Book I 'Psychology As a Science' of PES, that whereas physics, granting their tacit limitations 'which point to explanatory metaphysical hypotheses', can be defined as a science of pure physical phenomena in general (given to acts of outer perceptual-sense experience), [descriptive] psychology can be defined now as a science of psychical phenomena in general (given to acts of inner perception, and without any metaphysical explanatory hypotheses). ${ }^{42}$ At any rate, Brentano opens Book II 'Psychical Phenomena in General' of PES with the claim, ' $(T)$ he entire world of our appearances can be divided into two large classes, i.e., into the classes of physical and psychical phenomena; ${ }^{43}$ a division that he makes use of throughout Book I, but without any argumentation for that distinction. Providing the argumentation for that distinction, and clarifying the meaning of the physical and the psychical, as well as discussing the various ways in which acts present themselves immediately in consciousness

\footnotetext{
${ }^{41}$ If there is a specific experience of human consciousness as such that simply is not the concern and cannot be the concern of natural science, then this means just that - no more, no less. Consciousness no longer becomes important to natural science. This is what lies behind Kathleen V. Wilkes title of her article 'Is Consciousness Important?', British Journal for the Philosophy of Science, 35 (1984), 223-243, and before her article, behind William James's famous 1904-05 article, 'Does Consciousness Exist?' (reprinted in his Essays in Radical Empiricism (1912)). The latter is not an argument against either the existence or the significance of the experience of human consciousness as such, but an argument that consciousness, as we know it, is not examined by natural scientific theories. And we could add, if it is, one of the major consequence of this, as Maurice Nathanson succinctly puts it at the end of his paper, is that, '(T)he naturalization of consciousness is the philosophical death of consciousness' ('The Empirical and Transcendental Ego', in For Roman Ingarden: Nine Essays in Phenomenology, ed. by A-T.Tymieniecka (Hague: Nijhoff, 1959), pp. 42-53 (p. 53). There are, of course, several well-known and much discussed objections to any attempt to capture the essence of human consciousness, the main one being that there is no such thing as consciousness as such in the first place. If there is no such thing as buman consciousness as such, then any thesis about it (or its nature) is, of course, spurious. Proving that there is no such thing as human consciousness as such, however, is a disputed issue in both philosophy and science.

42 Husserl, 'Appendix', p. 858.

43 'Die gesamte Welt unserer Erscheinungen zerfällt in zwei große Klassen, in die Klasse der physichen und in die der psychischen Phänomene.' Zweites Buch. Von den psychischen Phänomenen im allgemeinen. p.108. Brentano's original italics retained and McAlister's et. al. English trans. mod.: 'All the data of consciousness are divided into two great classes - the class of physical and the class of mental phenomena.' PES, p. 77.
} 
(as acts of presentation, of judgement, and of love and hate or of the emotions, the three 'natural classes' identified and distinguished by Brentano according to the way in which the act is related to its object) becomes the main preoccupations of Book II 'Psychical Phenomena in Genera' of PES.

Asserting that there are two main classes of physical and psychical phenomena as domains of enquiry for natural science does not, however, as Brentano well knows, resolve the many difficulties and disputes that exist between natural scientists regarding what the physical and psychical is. In point of fact, at the beginning of Book II of PES Brentano draws attention to a very high level of 'confusion' among scientists over the meaning of these terms, noting that 'neither agreement nor complete clarity has been achieved regarding the delimitation of the two classes'. ${ }^{44} \mathrm{He}$ also informs us that he found 'no unanimity among psychologists' about the meaning of these basic terms for their own particular science. ${ }^{45}$ Furthermore, 'even important psychologists [citing J.S. Mill] maybe hard pressed to defend themselves against the charge of self-contradiction'. ${ }^{46}$ This 'lack of agreement' in relation to the meaning of what is the physical and what is the psychical, coupled with 'misuse', 'confusion', and 'self-contradiction' by some eminent scientists in their use of the terms, is, in Brentano's estimation, a major obstacle to the evolution of the natural sciences in general and to the budding new science of psychology in particular. As he writes, '(I)t is a sign of the immature state of psychology that we can scarcely utter a single sentence about psychical phenomena which will not be disputed by many people,. ${ }^{47}$ Faced with this scenario, Brentano declares, for Book II, '(O)ur aim [therefore,] is to clarify the meaning of the two terms "physical phenomenon" and "psychical phenomenon", removing all misunderstanding and confusion concerning them. And it does not matter to us what means we use, as long as they really serve to clarify these terms' ${ }^{48}$ Since Brentano, however, cannot settle this dispute about the meaning of these terms among psychologists and scientists by appealing to any well-founded theory elaborated in natural science itself, nor resolve this difficulty by drawing upon any (debatable) meaning which these terms may have enjoyed in any particular philosophical, historical or cultural understanding of the physical and the psychical, his only alternative is to check the meaning of these terms against the facts of experience itself. ${ }^{49}$ This is the only way in which Brentano believes that we can clarify the meaning of such terms as 'physical phenomena' and 'psychical phenomena' for all concerned, whether those concerned be natural scientists, the ordinary 'man-in-the-street', or the historian of philosophy. ${ }^{50}$ This, as Husserl correctly identifies, is Brentano's 'thought-motivation' in Book II of PES, and though Husserl has problems with Brentano's elaboration of the way in which Brentano actually determines the meanings of 'physical phenomena' and 'psychical phenomena' in relation to 'inner' and 'outer

\footnotetext{
44 Ibid., p. 77.

45 Ibid., p. 86.

46 Ibid., p. 77.

47 Ibid., p. 80.

48 Ibid., p. 78

49 This is what lies behind his remarks in his 1874 Foreword to PES, '(M)y psychological standpoint is empirical; experience alone is my teacher' (PES, p. xxvii). Brentano uses this to assess earlier efforts to distinguish various dimensions to the human soul or mind, from Plato and Aristotle, through some major thinkers of the Middle ages and modern philosophies, up to and including contemporary natural-scientific attempts in Book II, $\int$ V 'A Survey of the Principal Attempts to Classify Psychical Phenomena', pp. 177-193. ${ }^{50}$ Husserl agrees with this basic approach of Brentano and develops, as is well known, his particular view of phenomenology as the tracing back to perceptually-founded acts (in human consciousness) in the experiences of a valid normative logical consciousness as such in his Logical Investigations, and the experience of 'Being as thing' given to outer perceptual-sense experience and Being as (conscious) experience given to inner perception, in his (in)famous and celebrated reduction of the 'natural attitude' to the 'transcendentalphenomenological attitude' in Ideas I.
} 
perception', Husserl, nonetheless, believes that Brentano is on the right track in this 'interesting line of thought'. ${ }^{51}$

The explicit task, then, that Brentano set himself in Book II is not to rely on any natural scientific theories, or philosophical systems, or hypothetical-systematic analysis of physical and psychical phenomena, but to return to the facts of experience itself to clarify the meaning of these concepts against intuition. Notwithstanding these motivations, Brentano's starting point in his understanding of 'physical phenomena' and 'psychical phenomena' in Book II is not, however, as philosophically neutral or as theoretically untainted as he thinks it is. He does begin with 'examples' of both physical and psychical phenomena, rather than theories, but these examples are theory-laden.

Firstly, by 'physical phenomena', Brentano clearly means what Locke termed 'secondary qualities' (or what commentators today call qualia of sensory experience), for, as he tells us,

Examples of physical phenomena [...] are a colour, a figure, [...], a chord which I hear, warmth, cold, odour which I sense; as well as similar images which appear in the imagination. ${ }^{52}$

In fact, towards the beginning of Book I Brentano had already drawn attention to 'an experiment' that 'John Locke once conducted [...] in which, after having warmed one of his hands and cooled the other, he immersed both of them simultaneously in the same basin of water. He experienced warmth in one hand and cold in the other, and thus proved that neither warmth nor cold really existed in the water'. ${ }^{53}$ Brentano, indeed, argues even further than Locke, maintaining that the way in which things and their objective properties really and truly exist extra-mentally — that is to say, when we are not immediately and directly aware of them - are as 'atoms', 'light rays', 'forces' and so forth, that is to say, as whatever the natural sciences theoretically uncovers or discovers and studies. Brentano also, unfortunately, calls these theoretically constructed objects of natural science 'physical phenomena' too, but these are the very things that do not appear directly to (or in) consciousness. ${ }^{54}$ Thus we must recognise two different meanings with which Brentano operates for the one term of 'physical phenomena' in PES: in the first sense, physical phenomena are colours, sounds, odours, warmth etc., which enjoy phenomenal existence and exist as immanent objects' of actual acts of outer perceptual-sense experience; that is to say, they exist as the objects of those experiences, but exist only as long as the experience occurs. As Locke's experiment demonstrates, warmth only exists in the experiencing and not as objective properties of things existing extra-mentally (water). Physical phenomena, in the second sense, are the theoretically constructed objects of natural science (e.g., light-rays, sinewaves, forces, $\mathrm{H} 2 \mathrm{O}$, and so forth). When considered from a natural-scientific-theoretical point of view, these 'physical phenomena' enjoy actual existence, whether we are made aware of their actual existence through natural-scientific means, or not. The latter theoretically constructed objects of physics, however, are not the immediate and direct,

\footnotetext{
${ }^{51}$ Husserl, 'Appendix', p. 875.

52 PES, pp. 79-80: 112. The terminological switch from 'physical things' in his 1866 habilitation thesis on Aristotle's psychology to 'physical phenomena' (qua 'secondary qualities') should alert commentators to the shift from old to new modern science that Brentano now approves of.

53 PES, p. 9.

54 ' $\mathrm{I}$ believe that I will not be mistaken if I assume that the definition of natural science as the science of physical phenomena is frequently connected with the concept of forces belonging to a world which is similar to the one extended in space and flowing in time; forces which, through their influence on the sense organs, arouse sensation and mutually influence each other in their action, and of which natural science investigates the laws of co-existence and succession. If those objects are considered as the objects of natural sciences, there is also the advantage [over 'physical phenomena' considered as sensorial objects of actual acts of outer sense perception, as is evident from the context] that this science appears to have as its object something that really and truly exists'. PES, pp. 99-100.
} 
actual objects of outer perceptual-sense experience for Brentano. ${ }^{55}$ So, what are the actual objects that he claims consciousness is a consciousness of, and that his new science of 'descriptive psychology' is primarily interested in? The actual objects that consciousness is a consciousness of turns out to be the immediate and actual experiences themselves that the 'mentally active subject' enjoys or endures. ${ }^{56}$ For Brentano, then, the relation between consciousness and its objectivities, from a descriptive-psychological point of view, is entirely intra-psychical and self-contained. In this regard Brentano is clearly subscribing to some version of Hume's doctrine of ideas in which it is held that the mind, in all of its operations and transactions, never has directly available to itself anything but its own perceptions. ${ }^{57}$

If we turn to what Brentano means by 'psychical phenomena', these too turn out to be very similar to what Locke and Hume claim is what we perceive when consciousness reflects upon its own activities. By a 'psychical phenomenon', Brentano tells us, he means,

Hearing a sound, seeing a coloured object, feeling warmth or cold, [...] similar states of imagination, $[\ldots]$ the thinking of a general concept, [...] every judgement, every recollection, every expectation, every inference, every conviction or opinion, every doubt, [...] [and] every emotion. ${ }^{58}$

'Psychical phenomena', then, are identifiable, individual psychical act-experiences that a 'mentally active subject' has, as long as they are actually occurring for that mentally active subject. They include a very wide range of experiences, from involuntary sensations (of colours and sounds), to taking an interest in something, from judging something to be true or false, to imaging something, from misunderstanding something, to loving or hating something, from fearing something (ghosts or spiders), to hoping for something, from daydreaming, to taking a disinterested point of view, from making a moral judgement, to making a valid logical inference, from being certain about something, to being doubtful about something, from being sad, to being happy, and so forth.

\footnotetext{
55 'We have no right, therefore, that the objects of so-called outer perception really exist as they appear to us. Indeed, they demonstrably do not exist outside of us. In contrast to that which really and truly exists, they are mere phenomena'. PES, p. 10.

${ }^{56}$ Brentano, therefore, can play on the literal meaning of the German word 'Bewusstsein', to show that what consciousness is a-consciousness-of is, to be (sein) aware (Bewusst). Thus the German word itself, '(T)he term "consciousness", since it refers to an object which consciousness is a conscious of (von welchem das Bewusstsein Bewusstsein ist)', corroborates, Brentano believes, even his own famous definition of 'psychical act' / 'psychical phenomenon' that he had given earlier in the famous passage of PES (p. 88), 'in terms of its distinguishing characteristic, i.e., the property of the intentional [=mental] in-existence of an object, for which we lack a word in common usage' (PES, p. 102). Later, Heidegger will unpack the meaning of this etymology (like others before him, e.g., Marx) to stress it implies some 'meaning of Being', and that this is what determines 'consciousness', and not the other way around. This, of course, misconstrues the point that Brentano wishes to make, namely, that consciousness exists - the latter is 'the wonder of all wonders' as Husserl would later stress, following Brentano's descriptive-psychological stance. Such word-support does not work for the English term 'consciousness', of course; the latter, rather, stems from the Latin, 'con' (together) and 'scire' (to know), as in having shared knowledge with others, and thus is linked to 'moral conscience' (conscientiae). In a court of law, for instance, when one is charged with being 'an accessory after the fact (factum)', or of 'being conscious of the fact', one is being charged with being an accomplice or an witness to the deed done (factum) by somebody else. Thus the Latin phrase, 'conscius sibi' is translated into English as 'conscious to oneself, and it is with such 'internal testimony' that Descartes uses the term 'conscientia' in his starting-point of his philosophical analysis of the mind. Brentano follows Descartes.

57 Nothing is ever present to the mind but its perceptions; and [...] all the actions of seeing, hearing [...] fall under its denomination. The mind may never exert in any action which may not be comprehended under the term perception.' Treatise, p. 456/b. The influence of Hume on PES is extensive whereas in his previous published work The Psychology of Aristotle, In Particular His Doctrine of the Active Intellect (1867) it is non-existent. Between 1886 and 1974 Brentano undertakes extensive readings of Descartes, Locke, Berkeley, Hume, and some Kant, and many more works. It is this 'modern definition' and 'modern conception' of psychology (PES, pp. 18-19) that dominates his understanding of psychology/ philosophy as a science throughout the 1870s, 1880s and into the early 1890s. Brentano returns to his interest in Aristotle in the early 1900s.

58 PES, p. 79:111-112.
} 
Whether or not there exists a soul-substance as bearer of such 'psychical phenomena', we can, Brentano says, set this question aside because this is not an issue for the science of psychical phenomena. The only metaphysical commitment that Brentano believes he needs to subscribe to, in order to defend the 'modern definition' of psychology as a science of psychical phenomena, is 'that there are psychical phenomena'. Thus he concludes,

(F)or whether or not there are souls, the fact is that there are psychical phenomena [as evidently presented through 'inner perception']. Nothing, therefore, stands in our way if we adopt the modern definition [of psychology as the science of psychical phenomena] instead of defining psychology as the science of the soul. Perhaps both are correct. The differences, which still exist between them, are that the old definition contains metaphysical presuppositions from which the modern one is free [...]. Consequently, the adoption of the modern conception simplifies our work. Furthermore, it offers an additional advantage: any exclusion of an unrelated question not only simplifies, but also reinforces the work. It shows that the results of our investigations are dependent on fewer presuppositions, and thus lends greater certainty to our convictions. ${ }^{59}$

Brentano, therefore, believes that the 'modern conception' of psychology as a science of psychical phenomena does not contain any metaphysical presuppositions similar to the old definition of psychology as a science of the soul. It also seeks to have fewer epistemological presuppositions, thus enhancing its modern 'scientific' character. This, however, does not mean that the modern definition of psychology does not contain any metaphysical or epistemological presuppositions, for it clearly does; the most important one being that psychical phenomena exist and that their existence, as is evident from the context, is known (and guaranteed as such) via 'inner perception'. Questions pertaining to the existence of such phenomena, nevertheless, are simply not part of psychology as a science. It suffices for the study of psychical phenomena to begin with the fact that psychical phenomena exist. Yet Brentano takes the 'fact' that psychical phenomena exist to be a factually self-evident truth — that is to say, 'the inner perception of our own phenomena' needs no epistemic justification other than the fact that it is the case and it is true. It is this that furnishes the natural science of psychology with its special empirical and epistemological (irrefragable) basis. And if we take this basis exclusively as the foundation stone upon which the new science of psychology is to be built, we can, Brentano argues, define 'psychology', contra Aristotle and the Aristotelians, as a science 'without a soul'. ${ }^{60}$

The 'empirical standpoint' that Brentano endorses in PES, then, is simply a continuation of Hume's starting point, namely, the fact that there are psychical phenomena perceived in the mind: no more, no less. The origin of all our knowledge-claims about the human mind comes from these, just as Hume had argued. We could conclude, therefore, that in PES Brentano is adopting a Humean psycho-analytic approach to psychology in that the exclusive focus and concern is with the analysis of the contents of consciousness as they are immediately, discretely and directly given to consciousness (passively 'impressed' as Hume would put it), eschewing any metaphysical [= hypothetical] commitment to such things as 'substantial bearers' of 'personal identity', or external 'causes' from its considerations. ${ }^{61}$ That natural scientists examine such 'causes' of whatever arises in our consciousness that lie outside our experiences, Hume is in no doubt, and acknowledges this, but to Hume these are not important to his philosophical investigations into the human mind simply because, as one commentator succinctly puts it, 'Hume's "first maxim" is that "in the end we must rest content with experience". ${ }^{62}$ This is why Brentano

\footnotetext{
59 Ibid., p. 18-19.

60 Ibid., p.11

${ }^{61}$ See, PES, pp. 16-17, where Brentano directly quotes Hume's Treatise, Book I, IV, Sect.6., and his comments on this famous passage on the self as 'a bundle or collection of different perceptions'.

${ }^{62}$ See, supra, n. 16.
} 
himself maintains, following Hume, that he must, in his descriptive-psychological investigations, 'eschew metaphysical hypotheses', that is to say, block off any hypotheticaltheoretical entertainment of knowledge of that-which-is that resides outside of the experiencing subject. This, however, does not imply that Brentano does not subscribe (implicitly or explicitly) to any metaphysical suppositions regarding the nature of the 'existence' of 'psychical phenomena' (and 'physical phenomena') and the relation between an individual's 'consciousness' and 'body'. He clearly does (and I will return to these shortly). And he is also clearly aware of the fact that all empirical natural scientists, as we have already noted, subscribe to tacit metaphysical explanatory hypotheses in their science that are metaphysical presuppositions of their science about (1) the absolute nature of the existence of the external world outside of the experiencing subject, (2) the human being's sensory ability to perceive that world, and (3) the relationship between the human being and the external world. ${ }^{63}$ Since Brentano, however, is only concerned with establishing the existence of a subject-matter for the science of psychology he avers the minimalist metaphysical acceptance of the existence of 'psychical phenomena' in 'inner perception', without explaining or entertaining the relationship between consciousness and one's own body, or between my actual consciousness and the world that exists independently of one's own actual experiences. As far as Brentano is concerned, nonetheless, without inner perception of our own psychical phenomena' there would be literally no subject-matter for the natural science of psychology, or for any scientific endeavour, including the normative sciences of logic, ethics and aesthetics, to study and research — it is that significant for Brentano (as it was for Hume). ${ }^{64}$ 'Inner perception', after all, 'tells me that I am now having such-andsuch sound or colour sensations, or that I am now thinking or willing this or that. ${ }^{, 65}$ Outside of the experiences of consciousness that are characteristic of human experience, then, Brentano recognises and acknowledges the existence of, what Husserl calls, 'a factworld', but this is not the concern of Brentano's new science of descriptive psychology. Thus despite Brentano's reverence for Aristotle and the Scholastics, underpinning PES and $D P$ is Brentano's subscription to some version of Kant's two-domain theory, where one domain of enquiry posits and includes the experiences of a normatively valid logical, ethical and aesthetical consciousness as such and the other points to that which resides outside of the experiencing subject and that is examined deterministically by the natural sciences.

(ii) Some Important Epistemological, Phenomenological and Metaphysical Implications of Brentano's Doctrine of Inner Perception

Like Hume, Brentano believes that access to consciousness is 'peculiarly direct and certain as compared with our knowledge of anything else'. ${ }^{66}$ Coupled with this, Brentano subscribes to Locke's assumption that conscious acts cannot exist as conscious acts without being perceived all the time as conscious acts. ${ }^{67}$ Since psychical act-experiences are

\footnotetext{
${ }^{63}$ Husserl draws attention to these critical passages, quoting them in length, in his 'Appendix' to the Logical Investigations and praises Brentano for his acute observations of the tacit metaphysical presuppositions which natural science must adhere to in their scientific pursuits.

${ }^{64}$ In this approach, Brentano is following Hume. In the 'Introduction' to the Treatise, Hume writes, '(T)here is no question of importance whose decision is not comprised in the science of man; and there is none, which can be decided with any certainty, before we become acquainted with that science. In pretending therefore to explain the principles of human nature, we in effect propose a complete system of the sciences, built on a foundation almost entirely new, and the only one upon which they can stand with any security.' Everyman edition. p. 5; Selby-Bigge's edition, p. xx. As one commentator rhetorically remarks, 'What is this but a Scottish version of Kant's Copernican Revolution?' H. H. Price, Hume's Theory of the External World (Oxford: Oxford University Press, $1^{\text {st }}$ edn, 1940; 1967), p. 9.

${ }^{65}$ Brentano, On the Origin of our Knowledge of Right and Wrong, pp. 19-20.

${ }^{66}$ Passmore, $A$ Hundred Years of Philosophy, p. 178. Cf., also, PES, p. 91

${ }^{67}$ This, of course, echoes Locke's views - 'Consciousness is the perception of what passes in a man's own mind', (An Essay Concerning Human Understanding, Bk II, Ch. 1, 19.) — and, following Locke, this is why Brentano argues that we can do without the 'hypothesis of the unconscious' in the science of 'psychical
} 
being perceived all the time in their existence, 'conscious acts' cannot but show themselves as 'phenomena' to 'a mentally active subject'. Thus, for Brentano, the terms 'conscious act', 'consciousness', 'psychical act' and 'psychical phenomenon' are all 'synonymous expressions'. ${ }^{68}$ Here, then, we arrive at one of the main meanings of 'inner perception' for Brentano: 'an inner act of perceiving' that accompanies each and any actual experience or conscious act that the 'mentally active subject' enjoys. ${ }^{69}$ Husserl is critical of this part of Brentano's doctrine on inner perception, but before assessing his critique of Brentano's views we need to outline some important conclusions that Brentano draws from this part of his doctrine on 'inner perception'.

From this understanding of 'inner perception' as an 'inner act of perceiving', Brentano draws the following significant conclusions. Firstly, from both an ontological and phenomenological point of view, the very 'acts' or 'phenomena' of 'psychical phenomena' have, inextricably, both actual (wirklich) and phenomenal dimensions to their existence since in and through the inner act of perceiving experiences are perceived as what they are. Experiences, then, manifest their actual existence in their appearing to consciousness, and in their appearing to an actual human consciousness they are what they actually are (but only intra-psychically). Secondly, from an epistemological point of view, since the actual acts or phenomena that are known immediately are as they are, the knowledge obtained in such an inner act of perceiving is direct, non-hypothetical, self-evident and infallible. Thirdly, from an experiential point of view, all of this exists for the mentally active subject only as long as such psychical activity actually occurs (or is passively endured as Brentano holds). From a descriptive-psychological point of view, then, the causal origins of such 'conscious acts' or 'psychical phenomena' can be set aside, and any questions about their causal origins must be left to whatever advances that are made (and that can be made) in natural scientific developments of empirical psychology. Such questions and issues regarding their causal origins are to be left to that part of the science of empirical psychology which Brentano calls, in his Vienna lectures, 'genetic psychology'. ${ }^{70}$ Genetic psychology uses the method of the natural sciences (observation, hypotheses, experimentation). Descriptive psychology, by comparison, must set aside all theoretical (natural scientific and naturalistic) conceptions of psychical phenomena and, instead, try to describe non-hypothetically what 'psychical phenomena' are themselves. 'Another important difference', Brentano notes between the kind of knowledge-claims that are sought in descriptive psychology in comparison to the kind generated in genetic psychology, is that descriptive psychology 'is an exact science, and that in contrast, genetic psychology, in all its determinations, in an inexact one. ${ }^{71}$ By an exact science, Brentano means those 'sciences which can formulate their doctrines sharply and precisely', such as, for instance, 'a mathematician doesn't say: the sum of the angles of a triangle is often, or usually, equal to two right angles. But he says that this is always and without exception the case'. ${ }^{72}$ Since descriptive psychology seeks to remove confusion from its descriptions of

phenomena' because whatever is in consciousness must be consciously perceived. See, PES, Book II, Section II Inner Consciousness (pp. 101-137). What Brentano does not recognise, however, is that the belief that conscious acts are perceived automatically as conscious acts is itself a hypothesis that a new descriptive science of psychology can do without, and which Husserl does without in his development of Brentano's new science of descriptive psychology. Furthermore, what is in consciousness is not always conscious. Thus the question of the relation between consciousness and the unconscious is left unaddressed in Brentano's thinking, but it is an area that one of Brentano's other well-known students, Sigmund Freud, of course, pursued.

68 PES, p. 102:142-3. See also, supra, n. 56, and Brentano's comments on the link between the German word 'Bewusstsein' and the definition of a psychical act-experience as an act that contains an intentional [=mental], immanent object'.

${ }^{69}$ Others meanings are (2) inner perception as inner reflection; (3) inner perception as immanent perception;

(4) inner perception as 'incidental consciousness'. Each one of these meanings is discussed below.

70 See, supra, n. 6.

${ }^{71}$ DP, p. 4-5.

72 Ibid., p. 5. 
'psychical phenomena', descriptive psychology seeks this latter kind of precision and accuracy in its knowledge-claims. All natural scientific investigations, including genetic psychology, seek knowledge-claims that are true for the most part, but such truths are never necessarily true, and so, the 'stimulation of a retinal part [of the eye] by a light-ray of a certain frequency [which] induces the phenomenon of blue' does 'not always' induce the phenomenon of blue 'as it is not true in case of (a) colour-blindness, (b) interruption of the conductor, severance of the nerve, (c) losing in competition (Besiegtwerden im Wettstreit), (d) replacement by a hallucination'. ${ }^{73}$

This division by Brentano of the sciences into exact and inexact sciences corresponds, by and large, to the epistemological distinction that Hume famously draws between knowledge-claims pertaining to 'matters of fact' and to 'relation of ideas', and before Hume, to Leibniz's distinction between 'truths of fact' and 'truths of reason'. Descriptive psychology seeks 'vérités de raison', that is to say, items of knowledge that are eternally true. Descriptive psychology does not seek inductive, empirical generalisations the truth of which could always turn out to be otherwise than it is. In this respect, it is worth stressing the point that Brentano never employed the method of the natural sciences in his actual descriptive-psychological philosophizing and never proposed the method of the natural sciences for his new science of descriptive psychology. ${ }^{75}$ Nor did Brentano engage in any historical-hermeneutic analysis of the meaning of our experiences, in the radical and comprehensive manner that Dilthey, for instance, had advocated, and that Dilthey also had termed around this time, in the $1890 \mathrm{~s}$, 'descriptive psychology. ${ }^{76}$ In contrast to any such Diltheyean-bermeneutic approach, Brentano employed a more mathematical model of reasoning in his descriptive method because the task for the descriptive psychologist is to pick out those essential features that are intuitively demonstrable in all psychical actexperiences and their immanent objects that cannot, in an a priori manner of speaking, be known to be otherwise than they are. According to Brentano, the object-relatedness of all conscious acts, the 'intentionality of consciousness', is just one such discernible structure

\footnotetext{
73 Ibid., pp. 6-7.

${ }^{74}$ See, Oskar Kraus, 'Introduction to the 1924 Edition [of PES]', in 'Appendix' to PES, pp. 369-408 (p. 370).

${ }^{75} \mathrm{It}$ is often noted and pointed out by commentators that one of the twenty-four theses that Brentano publicly defended in his disputationes at Würzburg University in 1866 was the well-known thesis: 'The true method of philosophy is none other than that of the natural sciences.' Brentano never advocated the method of the natural sciences for the descriptive part of his new science of 'descriptive psychology' (for which, we can read 'philosophy'), which first emerged, albeit in embryonic form, in his unfinished study of PES, published in 1874, and which he subsequently developed in his lecture-courses on 'Descriptive Psychology' at Vienna University in the late 1880s and early 1890s. For his idea of a 'descriptive psychology' he advocated, instead, the 'evidence' of 'inner perception', or, more accurately stated, the ability of consciousness to reflect directly upon its own operations and discover, intuitively, non-hypothetical a priori 'truths of reason' about those contents. How descriptive-psychological truths that are by nature non-hypothetical, intuitively demonstrable and a priori knowledge-claims about consciousness and its objectivities are exactly related to, or complemented by natural-scientific knowledge-claims that are hypothetically ascertained, empirically verifiable and, by nature, both corrigible and probably true of the physical world about us, including ourselves as hypothesized 'things' in and of that world, does not feature as problematic in Brentano's thought. This problematic relation between philosophy as descriptive psychology and the natural sciences, however, does occupy Husserl's attention greatly in the development of his thought. See, Husserl, Ideas I, Ch 2., \ 40 "Primary" and "Secondary" Qualities. The Physical Thing Given "In Person" a "Mere Appearance" of the "True Physical Thing” Determined in Physics', and cf., Th. de Boer, 'The Meaning of Husserl's Idealism in the Light of His Development', trans. by H. Pietersma, Analecta Husserliana, 2 (1972), 322-332.

${ }^{76}$ Identity in terms is not, of course, equivalent to identity in concepts. Dilthey develops an entirely different concept of 'Descriptive Psychology' to that as advanced by Brentano (and Husserl). Cf., Wilhelm Dilthey, Descriptive Psychology and Historical Understanding, trans. by Richard M. Zaner \& Kenneth L. Heiges, (The Hague: Nijhoff, 1977); containing 'Ideas Concerning a Descriptive Psychology and Analytic Psychology (1894)', originally 'Ideen über eine beschreibende und zergliedernde Psychologie', Gesammelte Schriften, Band V. (Leipzig und Bern: Teubner, 1924), pp. 139-240. See, also, his, 'The Understanding of Other Persons and their Expressions of Life (ca. 1910)', 'Das Verstehen anderer Personen und ihrer Lebensäusserungen', Gemsammelte Schriften, Band VII (Leipzig und Berlin: Teubner, 1927), pp. 205-27.
} 
that is evidently true of the nature of psychical act-experiences themselves. Like all descriptive-psychological items of knowledge, this item of knowledge, the objectrelatedness of all psychical act-experiences, expresses, for Brentano, a 'truth of reason'. It is grasped 'at one stroke and without induction. ${ }^{, 77}$ Under these methodological constraints, Brentano believes that any descriptive-psychological knowledge of 'psychical phenomena' or 'conscious acts', gained by way of 'inner perception', will turn out to be immediate, direct, non-hypothetical, a priori, self-evident and infallible. ${ }^{78}$ All of this presupposes, of course, that Brentano subscribes, at least in some regard, to what is generally referred to today as the 'transparency thesis' (again following Descartes, Locke and Hume) regarding the kind of access that the mentally active subject has to that being's own particular conscious states, or beliefs, or whatever 'arises' in consciousness. Again, we can set this issue aside in our exposition of Brentano's doctrine of 'inner perception', but will return to it later, in the final section of this article, in our evaluation of Husserl's critique of 'Brentano's standpoint'.

(iii) The Results of Brentano's Comparison Between Inner and Outer Perception, Psychical and Physical Phenomena

Brentano tells us that his aim in Book II Psychical Phenomena in General of PES is to clarify the meaning of two terms, 'physical and psychical phenomena', removing 'all misunderstanding' and 'confusion' between them. Since Brentano wishes to clarify the meaning of what is the physical and what is the psychical, without appeal to any hypothetical theories and only to our experiences of those 'things themselves' (as Husserl would put it), he turns his attention to seeing what it is that distinguishes intuitively the experiences that are characteristic of inner perception and outer (sense) perception. When Brentano compares the 'outer [sense] perception' of 'physical phenomena' to the 'inner perception' of 'psychical phenomena', dramatic differences, on ontological, epistemological and phenomenological grounds, reveal themselves; or, at least, so Brentano thinks. He arrives at the following conclusions, not all of which Husserl accepts as legitimate conclusions that can be or should have been drawn from a descriptive-psychological methodological point of view. We need to outline and understand Brentano's conclusions first, however.

Knowledge of 'physical phenomena' given to outer (sense) perception is direct, like the knowledge of inner perception, but, unlike inner perception, such outer (sense) perception, Brentano claims, is inherently deceptive or misleading. Why? To understand Brentano's views here, we need to return to the two meanings he has for 'physical phenomena'. Firstly, by physical phenomena, Brentano says he means a sound I hear, a colour I see, an odour I smell and so forth, that is to say, so-called secondary qualities. Since colours and sounds, when we are not directly aware of them, do not exist as colours or sounds in their respective objects, but as determined by the theories of natural science (e.g. as light rays or light particles, sine waves, or atoms, or forces etc..), then in outer perception we take (nehmen) such colours to really exist in the extra-mental reality whereas this is not the way they actually (wirklich) exist. Thus outer (sense) perception is naturally but inherently mis-leading. The phenomenal colours, rather, are 'signs' of an extra-mental reality

\footnotetext{
77 O. Kraus, 'Introduction to the 1924 Edition [of PES]', in 'Appendix' to PES, pp. 396-408, (p. 370). 'This point', Kraus continues, 'was made by Brentano in his work The Origin of Our Knowledge of Right and Wrong in 1889'. Ibid.

${ }^{78}$ In PES Brentano believed that just as physics had established itself as 'the science of pure physical phenomena', so too psychology could become the natural science of 'psychical phenomena in general' (pp. 98-100). It is only after PES that Brentano realised the autonomous methodological nature of the 'descriptive part' of psychology, independently of all natural-scientific manner of inquiry [ = 'metaphysical hypotheses', PES, p. 64]. Spiegelberg concludes that because Brentano's very idea of descriptive psychology, right from its inception, entails 'a peculiar intuitive examination of the phenomena [of consciousness]', it 'establishes itself as an autonomous enterprise, if not as a separate one' from all other established natural sciences, such as, for instance, 'psychophysics and physiological psychology'. The Phenomenological Movement: A Historical Introduction (1994), p. 35.
} 
that really exists as determined by theoretical insights and discoveries of natural science. ${ }^{79}$ Thus this is why Brentano concludes that '(We) have no right, therefore, to believe that the objects of so-called outer perception really exist as they appear to us. Indeed, they demonstrably [as shown through natural science, as is evident from the context] do not exist [as properties of the objects, qua colours, etc.] outside of us. In contrast to that which really and truly exists [atoms, light-rays, light particles], they [colours] are mere phenomena' ${ }^{80}$ If, therefore, we admit the evidence of natural science into the descriptive psychological analysis of the outer (sense) perception of physical phenomena - and Brentano does, and Husserl is sharply critical of Brentano for doing this as part of his descriptive-psychological investigations which is supposed to exclude methodologically all such natural-scientific theoretical reasoning - then it follows that outer (sense) perception is inherently false-grasping (Falsch-nehmung). Furthermore, since Brentano admits of only two forms of perception, Brentano is forced to admit and stress the point, relying on the literal etymology of 'Wabrnebmung' as 'truthgrasping': 'In the strict sense of the term, they [psychical phenomena] alone are perceived [=truly grasped as they actually are]. On this basis we proceeded to define them as the only phenomena [in comparison to physical phenomena qua qualia] which possess actual existence in addition to intentional [mental] existence. ${ }^{81}$

Brentano's doctrine on 'inner perception', then, clearly has metaphysical implications. Whereas the psychical act-experiences exist as they are in their appearing to inner perception, physical phenomena, in their appearing to outer (sense) perception, have only phenomenal existence and do not exist as they actually are (that is to say, they do not exist extra-mentally as real properties of 'substances', for example, as Aristotle and the Aristotelians hold). By comparison to the actual existence of both psychical act-experiences (given in inner perception) and the objects of physics ('physical phenomena' in the second sense of light rays/ sine waves etc.,), 'physical phenomena' (in the first sense, i.e., colours, sounds) have be said to have only 'intentional' (as opposed to 'real') or 'mental' existence. Thus Brentano believes that he has established a clear division between psychical phenomena and physical phenomena on intuitively demonstrable grounds, as well as on a self-evident metaphysical basis pertaining to the very kind of existence that marks both the physical and the psychical. Psychical phenomena (psychical act-experiences) exist as they actually are, and are perceived as they are, and are known infallibly to be as they are, whereas physical phenomena (qua qualia) do not have actual existence (outside of the mind), are perceived not as they are (outside of the mind), and are known directly but falsely to be as they are (outside of the mind). Physical phenomena qua 'objects of physics' have actual existence, but not phenomenal existence. Thus the inner perception of psychical phenomena and the outer perception of physical phenomena distinguish themselves on epistemological, phenomenological, and metaphysical grounds.

There are several problems here, however, that Brentano either simply does not see, or believes not to be related to his views of psychology. Firstly, we do not know whether Brentano subscribes to an univocal or an equivocal view of 'actual existence' in his understanding of the 'actual existence' of 'psychical phenomena' and the 'actual existence' of the 'objects of physics'; nor does Brentano see any problem here with their co-existence. We do know, however, that he does not equate the existence of the brain with the

\footnotetext{
${ }^{79}$ If we assume that natural science will provide the 'basis' for all such knowledge claims, then this is a version of what Timm Triplett calls 'Theoretical Basics Foundationalism', in his paper, 'Recent Work on Foundationalism', American Philosophical Quarterly, 27 (1990), 93-116 (p. 98). This particular version of foundationalism (that Cornman identifies), Triplett remarks, 'would hold that the theoretical statements of science are basic, being epistemologically prior to propositions about subjective psychological states and to ordinary singular propositions about the external world. However, I do not find any clear advocacy of such a view in the literature' (ibid.). This is the position that Brentano, nonetheless, appears to hold in PES.

80 PES, p. 10, my emphasis.

${ }^{81}$ Ibid., p. 97-8, Brentano's emphasis.
} 
existence of conscious states, ${ }^{82}$ but since such 'metaphysical questions' are not part of 'descriptive psychology', he believes that he can set them aside and concentrate on 'the fact that psychical phenomena exist', and this is warranted on the basis of direct, nonhypothetical, infallible inner perceptions. Thus Brentano thinks he can distinguish both physical phenomena from psychical phenomena and outer perception from inner perception, on clearly defined and mutually exclusive kinds of phenomena presented in consciousness e.g., a tone (physical phenomenon) that is given to outer (sense) perception is not the hearing of a tone (psychical phenomena) given to inner perception, and on associated epistemological evidence grounded in perceptually founded act-experiences, e.g., inner perception is infallible and outer perception is inherently misleading (as the tone really and truly exists as sound waves etc.).

\section{Husserl's CRITIQue of Brentano’s DOCTRINE OF INNER PERCEPTION}

Husserl finds several faults with Brentano's account of inner and outer perception and the epistemological and phenomenological parallelism that he draws between psychical and physical phenomena on the basis of (alleged) self-evident characteristic features of inner and outer perception. Husserl's objections to Brentano's views can be found in many of Husserl's work, but he clearly felt the need to draw attention to these in relation to the elaboration of his own philosophy, for, on the occasion of the re-issue of his Logical Investigations (1900-01) in 1913, he specifically wrote and attached an 'Appendix. Outer and Inner Perception: Physical and Psychical Phenomena', wherein he singles out 'the standpoint of Brentano' and, after giving an account of 'the interesting line of thought' expounded by Brentano in PES, separates what appears to him to be 'what is indubitably significant in Brentano's thought-motivation from what is erroneous in its elaboration'. 83 We will concentrate mainly on Husserl's objections to 'inner perception' and the significance of those to Husserl's development of a different method of analysis for phenomenology.

Firstly, Husserl rejects, on experiential grounds, Brentano's claim (following Locke's) that all conscious acts are perceived by another inner, conscious act of perception. There is, Husserl correctly notes, no evidence for this occurring in our actual experiences. In point of fact, many experiences, e.g., anger, cannot admit of such conscious perception, for, if one were to become conscious of one's anger such would render it out of existence, or, at least, modify it significantly. Experiences (Erlebnisse), Husserl remarks, are not always and inherently being perceived all the time, as Brentano, following this Lockean hypothesis, believes them to be; they are, rather, simply things that are lived through (er-lebt). Experiences can be perceived, or are ready to be perceived, if, and only if, Husserl argues, we turn our attention away from objects given to outer perceptual-sense experience and reflect upon the nature of psychical act-experiences themselves. In other words, when inner perception means the ability of consciousness to reflect upon its own activity, this is an entirely correct and legitimate 'method' to be employed in any descriptive science of

\footnotetext{
82 Brentano also maintains that 'the relation of one human being to another, as far as their inner life is concerned, is in no way comparable to that which exists between two inorganic individuals of the same species, e.g., between two drops of water' (PES, p. 36). Whatever about comparing the incomparable - the relation between two inorganic individuals and the inner life of two human beings - Brentano believes that the way I can know the mental life of another human being is by way of analogy (!), based upon the inner perception of one's own mental phenomena: ' $(F)$ or, someone else can no more apprehend my psychical phenomena through inner perception that I can those that belong to him' (ibid., p. 37). By comparison to 'the direct perception of our own psychical phenomena we have', Brentano stresses, 'an indirect knowledge of the mental phenomena of others' (ibid.). His methodological doctrine of 'inner perception', therefore, prevents him for acknowledging the recognition of another directly as other, as an experiential fact of one's own mental life.

${ }^{83}$ Husserl, 'Appendix', esp., IS 2, 3, 4.
} 
psychical act-experiences and their objectivities (if they exist), as Brentano proposes. When Brentano, therefore, advocates 'inner perception' as a method of inner reflection, rather than as an accompanying inner percept, Husserl agrees with this part of his doctrine on 'inner perception', and makes the first small, but significant correction to Brentano's definition of 'descriptive psychology' on this basis: since psychical act-experiences are not concomitantly perceived all the time, 'descriptive psychology' is not a science of psychical phenomena, as Brentano suggests, it is, rather, simply a science of experiences (or, more accurately stated, of intentional psychical act-experiences (Erlebnisse) and their objectivities). ${ }^{84}$ Secondly, experiences are the kinds of things that cannot but be lived, this both Brentano and Husserl assume to be the case, at least implicitly and without any argumentation, but why experiences are given (at all) is not an issue for either Brentano or Husserl from a descriptivepsychological methodological point of view. In other words, a descriptive-psychological methodological point of view evades (rather than addresses or solves) the entire question relating to whether anything corresponds, in existence, to whatever consciousness is a consciousness of extra-mentally, or what kind of existence characterizes psychical actexperiences themselves. Why such experiences are needed by a human being, or by the human organism to survive on this planet is not part of descriptive psychology either. Such issues may well be entertained by other natural scientists in their hypothetical enquiries, but any such metaphysical explanatory hypotheses are simply not part of 'descriptive psychology'. This much Husserl agrees with Brentano. Descriptive psychology is a science of experiences. Experiencing something, nevertheless, is not knowing what that experience is, or even knowing that that experience is. This much Husserl does not agree with Brentano. Experience is just experience that one lives through. And if one learns what 'psychical act-experiences' ('psychical phenomena') are through 'inner perception', as Brentano believes, one cannot do this without reflection, that is to say, without reflecting on such experience and making judgements that are true of such experiences. Whatever knowledge is, or may be, knowledge, as both Brentano and Husserl (and anybody else) know, cannot but be a product of reflection (of some sort). It is, then, only through reflection on consciousness about the nature of consciousness itself that we can have and do have any knowledge of consciousness. This is the way to know things about consciousness. Thus, when 'inner perception' means 'inner reflection', this is the method that is to be deployed, at least initially, in any 'descriptive science' of consciousness and its objectivities themselves. As Husserl succinctly puts it in Ideas I,

Reflection is a name for acts (ein Titel für Akte) in which the stream of mental processes (Erlebnisstrom), with all its manifold occurrences (mental process-moments, intentionalia) become evidentially apprehensible and analysable (evident faßbar und analysierbar). It is, as we can also say, the name of the method of consciousness leading to the cognition of any consciousness whatever (Sie ist, so können wir es auch ausdrücken, der Titel der Bewußtseinsmethode für die Erkenntnis von Bewnsßtsein überbaupt). ${ }^{85}$

When we use this method of 'inner reflection' (which Brentano calls 'inner perception'), however, such reflection (inner perception), from an epistemological point of view, is, Husserl argues against Brentano, as naturally subject to error as is outer (sense) perception. 'In the percept of a toothache, e.g., a real experience is perceived, and yet our perception often deceives: the pain appears to bore a sound tooth.' Thus Husserl concludes from this,

\footnotetext{
${ }^{84}$ Husserl, Logical Investigations, Investigation V, $\int 13$. 'The Fixing of our Terminology', and previous section $\int$ 11. 'Avoidance of Verbally Tempting Misunderstandings. (a) The "Mental" of "Immanent" Object'.

${ }^{85}$ Ideas I, $\int 77$ The Phenomenological Study of Reflections on Mental Processes (Erlebnisreflexionen), p. 177:147. This is what lies behind Husserl's methodological insistence on giving up authority and tradition in any practice of 'phenomenological seeing' in his 'phenomenological workshops' at Freiburg University, as Heidegger recounts and which he attended in 1919. See, Martin Heidegger, 'My Way into Phenomenology', in Heidegger, On Time and Being, trans. by Joan Stambaugh (New York: Harper \& Row, 1972), p. 79.
} 
' $(T)$ he possibility of our error is plain. The perceived object is not the pain as experienced, but the pain in a transcendent reference as connected with tooth' ${ }^{86}$ Even in cases where the origin of the experience is not directly related to the nature of our incarnate consciousness or embodied experiences - and Husserl does not return to these in Ideas I, or in his other works - error is possible. For example, I can reflect upon my experiences, say, reflect on a memory, and believe something that is not the case. I could recall being taught Latin by Master McLoughlin in Sixth Form at School, but, in fact, it had been Master Harkin. Perception based upon reflection on 'pure' experiences is not, therefore, inherently infallible, as Brentano claims. They can be correct or incorrect (or 'adequate' or 'inadequate', as Husserl prefers to characterize them). They are fallible, just like our experiences of outer (sense) perception. If we confine ourselves to the acts of natural, outer perceptual-sense experience, as any descriptive clarification of 'physical phenomenon' methodologically requires us to do, we can perceive a green apple on the table, judge it to be a green apple, and it is a green apple, and so, know it is a green apple; on another occasion, we could perceive a green apple on the table, judge it to be a green apple, but on closer inspection, perceive it to be a green pear and it is a green pear. From a descriptivepsychological point of view, outer sense perception is not, as Brentano holds, inherently misleading on account of the discovery of natural sciences (of light rays/ light particles and inverted images in the retina etc.,) precisely because such theoretical discoveries of the natural sciences should not be entertained in any descriptive-psychological clarification of the meaning of 'physical phenomena' as given to actual outer perceptual-sense experiences. This does not mean, however, that Husserl returns to some form of Aristotelian substanceaccident distinction; rather, he argues that when colours and sounds (etc.) are given to our actual outer perceptual-sense experiences, we do not see colours and sounds as the intended objects of those acts but we interpret such sensations through objectivating acts of perception, or, at least, this is what Husserl maintains in the Logical Investigations: 'I perceive [...] that this box is square and brown in colour'. I do not hear sounds, rather, 'I hear a barrel organ - the tones sensed are interpreted as those of a barrel organ. In the same way I apperceivingly perceive my own psychical phenomena, the blessedness quivering through "me", the grief in my heart etc' ${ }^{87}$ We interpret such sensations through objectivating acts of perception, or, at least, this is what Husserl maintains in the Logical Investigations. This, however, does not imply that such outer (sense) perception is inherently infallible (in the way Brentano thinks inner perception is infallible). For example, in seeing an apple on the table, one could mistakingly take (interpret) the green of an apple for the green of a pear. On closer inspection, via outer (sense) perceptions, we could realise the green of an apple is the green of a pear, but such natural perceptual fallibility is to be expected of outer (sense) perception; to expect otherwise, e.g., apodictic indubitability, of sense experience, Husserl notes against Descartes and others, is unrealistic and contrary to the evidence of our actual experience of sense perceptions. Thus it does not follow from this that Husserl, in the Logical Investigations, defends a realist view of sense perception in maintaining 'sense data' are interpreted as those of the object (the brown of a leaf, the red of the box, the tones of a barrel organ) because this is an activity of consciousness, as Husserl explicitly argues. I could, for example, hear a knock at the door and interpret those audible sensations as somebody knocking at the door, but, in fact, it could be a broom falling against the door. This active relation between consciousness and its intended objects, nonetheless, leads Husserl to the view that even in outer perceptual-sense experience consciousness is not passive but active in the generation of meaning and this, in turn, leads Husserl to develop a theory of 'sense bestowing' (Sinngebung) power of consciousness that Brentano's descriptive-

\footnotetext{
${ }^{86}$ Husserl, 'Appendix', $₫ 7$.

${ }^{87}$ Husserl, 'Appendix', \4. The words used by Husserl are 'Deutung', 'Interpretation', or 'Apperception'. See, Logical Investigations, Investigation V, $\sqrt{ }$ 2. 'First Sense: Consciousness as the Real Phenomenological Unity of the Ego's Experiences. The Concept of an Experience'.
} 
psychological 'empirical standpoint' simply cannot and does not possess. Yet this is not 'a turn towards the object', in any philosophical realist sense, as many who followed Husserl of the Logical Investigations, against Husserl's own correct insistence, alas, believed it to be.

For Husserl, therefore, natural reflections on one's own mental states, as much as on the directly intended objects given to outer (sense) perception, are, from a descriptivepsychological methodological point of view, of equal epistemological value - both are subject to error, but outer perception is not inherently misleading and inner perception (reflection) is not inherently infallible. Thus Brentano cannot, on descriptive-psychologicalepistemological grounds, distinguish outer and inner perception on the basis that one is inherently misleading and the other inherently infallible.

In Ideas I, however, Husserl makes a very important distinction between what he calls acts within consciousness that are transcendentally directed and acts within consciousness that are immanently directed that Brentano does not make but which deserves our attention.

Unlike an act of transcendent perception that occurs within consciousness, such as, for instance, an act of recollection, which posits the existence of its object, a remembered item, sometimes correctly and sometimes not so correctly, an act of immanent perception posits knowledge of the existence of its object, the current (conscious) experience, without any shadow of doubt. It is not necessary, for instance, that a remembered experience exists, but it is necessary that an experience, immanently perceived, exists. ${ }^{88}$ Though limited strictly to the present, reflective immanent perception, nonetheless, is infallible in guaranteeing its knowledge of the existence (die Existenz) of its object. ${ }^{89}$ The non-existence of an experience immanently perceived is unthinkable, and it is unthinkable 'not', as Husserl had already remarked in the Logical Investigations, in the subjective [psychological-factual] sense of an incapacity to represent-things-otherwise, but in the objectively-ideal necessity of an inability-to-be-otherwise. ${ }^{90}$ In the immanent, reflective perception of an experience, therefore, what we encounter is not a merely factual-assertoric certainty (as Brentano held), but an apodictic certainty regarding knowledge of the existence of an experience. ${ }^{91}$ Husserl draws important implications from this in his famous argument for the 'absolute' existence of being as experience (Sein als Erlebnis) in comparison to the 'relative' existence of 'being as thing' (Sein als Ding) given to outer sense perception in his famous 'reduction' of the

\footnotetext{
88 Thus de Boer remarks, 'we can see why Husserl distinguishes within the sphere of immanently directed acts between immanent perception and other immanently directed acts such as remembering of an "experience". It is possible for the remembered experience not to exist. In memory no absolute positing is possible. Only in immanent perception is absolute positing possible.' The Development of Husserl's Thought, p. 345.

${ }^{89}$ That the very mode of being of that which that is given to our experiences is guaranteed on the basis of some identifiable, perceptually-founded act(s) is of crucial importance to Husserl's idea of a phenomenological philosophy because, otherwise, there would be no justification for any phenomenological approach to experience, as Husserl defines that approach. Not all of Husserl's so-called followers, however, agreed with Husserl on this point. The act of reflective, immanent perception, nonetheless, is of particular importance to Husserl in that it guarantees, apodictically, the very existence of its object, namely, psychical act-experiences and their objects (if they exist).

90 What cannot be thought, cannot be, what cannot be, cannot be thought - this equivalence fixes the differences between the pregnant notion of thinking and the ordinary subjective sense of presentation and thought. [...] Wherever therefore the word "can" occurs in conjunction with the pregnant use of "think", there is a reference, not to a subjective necessity, i.e. to the subjective incapacity-to-represent-thingsotherwise, but to the objectively-ideal necessity of an inability-to-be-otherwise.' Husserl, Logical Investigations, pp. 445-446.

$91^{~ ' E v e r y ~ p e r c e p t i o n ~ o f ~ s o m e t h i n g ~ i m m a n e n t l y ~ p e r c e i v e d ~ g u a r a n t e e s ~ t h e ~ e x i s t e n c e ~(d i e ~ E x i s t e n z) ~ o f ~ i t s ~ o b j e c t . ~}$ If reflective experience is directed towards my experience, I have seized something absolute in itself, the factual being (Dasein [not in Heidegger's sense of this term]) of which is essentially incapable of being negated, i.e., the insight that it is essentially impossible for it not to exist; it would be a countersense (ein Widersinn, a non-sense) to believe it possible that an experience given in that manner (so gegebenes) does not in truth exist'. Husserl, Ideas I, pp. 96-97:85.
} 
'natural attitude' to the 'transcendental-phenomenological attitude', but we can set this aside for the moment.

Brentano, however, makes no such distinction between 'inner perception' as an act of natural reflection and as an act of 'reflective immanent perception', nor between 'transcendent perception' and 'immanent perception' that can occur and be evidentially verifiable in consciousness itself. In the establishment of the existence of a subject-matter for an 'empirical' psychology, nonetheless, Brentano does subscribe to inner perception as an act of reflective immanent perception, at least in some embryonic form, for, as he argues, defending the absolute value of this form of perception, '(I)n the case of cognition through inner perception, what we perceive is that a psychical act exists. ${ }^{92}$ Indeed, in PES Brentano is very much aware of the philosophical debate that had arisen, since Kant, regarding whether 'existence' can be regarded as a real predicate, or not. He thinks, however, that this is a misguided way of approaching the question because a judgement can be made about existence that involves neither affirming nor denying a predicate of a subject term (e.g., Es donnert, it thunders). ${ }^{93}$ He agrees with Kant's point, nevertheless, that existence is not a real predicate, but on the basis of 'inner perception', that is to say, arguing 'how improbable (wie unwahrscheinlich), indeed impossible (unmöglich)' it is to hold the view that we can attach 'existence' to psychical act-experiences in an act of inner perception (i.e., reflective, immanent perception) for, as he points out, and this is worth quoting in length,

Philosophers are not in agreement as to what the term 'existence' really means, even though not only they, but any ordinary person, knows how to apply the term with confidence. But it does not seem difficult to see that it [die Existeng] is a very general and hence a very abstract concept, even if it really was derived from experience and did not exist in us as an a priori concept prior to all experience (always an awkward assumption). Would it be conceivable [...] that the very first sensation a child has is accompanied not only by a presentation (Vorstellung) of the act of sensation, but also at the same time by a perception of this act? By a cognition that it exists? By a judgement which connects the concept of existence as predicate with the psychical phenomenon as subject? I believe that everyone recognizes how improbable, indeed how impossible such a supposition is.

[...] [this] received theory of judgement [... that] every judgement which is expressed in the existential proposition adds the concept of existence to some subject-concept or other [...] is mistaken, because a compounding of subject and predicate is not at all essential to the nature of judgement. The distinction between these two elements has to do, rather, with a commonly used form of linguistic expression. In cognition through inner perception $[=$ 'reflective immanent perception'] we have before us in particular a judgement which quite obviously contradicts the usual view of psychologists and logicians. No one who pays attention to what goes on within himself [ $=$ in an act of immanent reflective perception] when he hears or sees and perceives his act of hearing or seeing could be mistaken about the fact that this judgement of inner perception [read reflective immanent perception] does not consist in the connection of a mental act as subject with existence as predicate, but consists rather in the simple [ $=$ direct $]$ affirmation of the psychical phenomenon [the current experience] which is present in inner consciousness. ${ }^{94}$

Thus Husserl is quite right to draw out the implication from Brentano's doctrine of 'inner perception' that, when it refers to an act of 'reflective immanent perception', knowledge of an experience in reflective immanent perception, limited strictly though it is to the present, is apodictic, and not just factually assertoric as Brentano holds. It is only in immanent perception, not in the ability to reflect upon experiences, nonetheless, that the nonexistence of a current experience is unthinkable. Because Brentano does make any distinction here he goes no further with this, but we do know that Husserl does go further with this insight in his establishment of the absolute mode of being that is characteristic of

\footnotetext{
92 PES, p. 141, my emphasis

${ }^{93}$ See, PES, pp. 210-221. See, also, Brentano's article 'Miklosich on Subjectless Propositions', reprinted in the Appendix to his 1889 publication The Origin of our Knowledge of Right and Wrong.

94 PES, pp. 141-142.
} 
'being as (conscious) experience' (Sein als Erlebnis) in comparison to the presumptive (relative) mode of being that is characteristic of being as thing (Sein als Ding) given to acts of outer perceptual-sense experience in his (in)famous methodological reduction of the natural attitude to the transcendental-phenomenological attitude in Ideas I. At least part of the origins of Husserl's latter 'transcendental method' of enquiry, therefore, is both a continuation and a radicalization of Brentano's ideas on 'inner perception', even if Brentano himself does not see this.

There are further distinctions that Husserl notes in Ideas I, and that Brentano does not entertain, but which are of pivotal importance to Husserl's development of a particular 'method' for the study of consciousness and its objectivities.

Reflective immanent perception, Husserl remarks, implies that there is present in an act of reflective immanent perception a discernible difference between the experience as lived and the experience as reflected upon, even though these two parts form one concrete cogitatio and one indissoluble, inherent unity of that perception. ${ }^{95}$ Talking about the experiencing of 'a rejoicing at a course of theoretical thought which goes on freely and fruitfully' - here (as is evident from the context) Husserl is thinking of the delight that one takes in the discovery of an objective truth, such as, for instance, the truth of a mathematical proposition or of a mathematical theorem, the gaudium de veritate of Augustine - Husserl remarks, 'we have the possibility of effecting a reflection on the reflection which objectivates the latter [ $=$ the reflective immanent perception] and of thus making even more effectively clear the difference between a rejoicing which is lived (erlebt), but not regarded, and a regarded (erblicket) rejoicing. ${ }^{96}$ "The first reflection on the rejoicing', Husserl notes, 'finds it as actually present now, but not [Husserl emphasizes] as only now beginning. [Rather,] It is there as continuing [as Husserl also emphasizes] to endure, as already lived before, just not looked at. ${ }^{97}$

Three things are of note here. Firstly, for Husserl, the ability of consciousness to engage in reflection on its own experiences does not bring such experiences into existence - their esse is not their percipi, as Berkeley would put it; for Husserl, rather, experiences are there, and exist, whether reflected upon, or not, and whether seen, or not. ${ }^{98}$ Secondly, Husserl is well aware of the fact that experiences are the kinds of things that cannot but be lived and cannot but be lived now, continuing in time, whether they are reflected upon, or

\footnotetext{
95 The perception of the experience in immanent perception and the experience itself are, therefore, nonindependent parts of that particular experience. In this instance, as de Boer comments, '(T)he perception cannot be isolated from its object; it is a non-independent aspect of this unity' (The Development of Husserl's Thought, p. 333).

${ }^{96}$ Husserl, Ideas I, p. 176:146. This position, however, is premised on a dualistic metaphysics of human subjectivity regarding the existence of a lucid mind and an opaque body, and is one place where later existential phenomenologists sought to correct Husserl's account of both the purity and the priority of 'pure intentional consciousness' argued for and defended in his famous reduction of the natural attitude to the transcendental-phenomenological attitude in Ideas $I$.

${ }^{97}$ Husserl, Ideas I, p. 176:146.

${ }^{98}$ See, Ideas I, '\$78. The Phenomenological Study of Reflections on Experiences,' pp. 177-181:147-151. For Husserl, then, reflective immanent perception does bring knowledge of those experiences into existence. That these experiences exist, however, drops out of Husserl's fundamental consideration of phenomenology. Heidegger follows suit in excluding such a metaphysical issue in Being and Time, for, as he both asserts and stresses, '(E)ntities [Seiendes] are [ist], quite independently [unabhängig] of the experiences by which they are disclosed, the acquaintance in which they are discovered, and the grasping in which their nature is ascertained. But [the meaning of] Being "is" ["ist"] only in the understanding of those entities to whose Being something like an understanding of Being [Seinsverständis] belongs.' (p. 228:183). This issue concerning the very existence of experiences and the very existence of things that are (however the latter are to be understood, or grasped, or constituted in our human understanding) becomes a fundamental consideration in Emmanuel Levinas's work in phenomenology. See, E. Levinas, Discovering Existence with Husserl, trans. and ed. by Richard A. Cohen \& Michael B. Smith (Illinois: Northwestern University Press, 1998); truncated version of his, En découvrant l'existence avec Husserl et Heidegger (Paris: Vrin, 1949; $2^{\text {nd }}$ expanded ed., 1967, 1974).
} 
not. ${ }^{99}$ Thirdly, and this is of most significance to Husserl, in any actual enactment of a reflective, immanent perception of an experience, a direct experiential understanding of 'the living now of the experience (das lebendige Jetzt des Erlebnisses)' is 'recoverable (wiederholbar)' and entertained by and in human consciousness itself. ${ }^{100}$

It thus follows for Husserl that experiences are not inherently 'phenomena' at all precisely because they are not being seen automatically or concomitantly all the time in consciousness, as Brentano, following Locke's hypothesis of an 'accompanying inner percept', would have us believe. ${ }^{101}$ On the contrary, more often than not experiences are not seen (for what they are), nor reflected upon; they are, rather, simply lived through (erlebt). Experiences, nonetheless, are always, in principle, 'ready to be perceived' either in a glance of 'straightforward reflection' or in 'reflective immanent perception', which is what Husserl is really thinking of in particular in his famous argument of the reduction of the natural attitude to the transcendental-phenomenological attitude. ${ }^{102}$

There are also many different types or kinds of unities that can and do exist in consciousness, and within consciousness, and that need to be further distinguished, if we are to follow Husserl on his advancement of Brentano's reflections on the unity of consciousness in PES. We shall only consider two that are most relevant to Husserl's development of a particular method of inquiry for the study of consciousness and its objectivities, as proposed by Brentano but not recognised by Brentano as a development of his ideas.

Firstly, Husserl remarks, the knowledge we can have of the unity pertaining to an act of reflective immanent perception and its object is distinctly different to the kind of knowledge that we can also have of the unity that characterizes 'the stream of experiences' for reflection. ${ }^{103}$ This is of crucial importance both to Husserl's line of argument and to his

\footnotetext{
${ }^{99}$ Husserl was well aware of the fact that 'time' was central to the determination of mode of 'being of (conscious) experience' (Sein als Erlebnis) and that the ability of consciousness to reflect on anything whatsoever, including its own contents, presupposed an immanent time-structure to the being of our experiences but because he had to prove that the particular kind of existence that is characteristic of psychical act-experiences cannot be reduced to thing-perception, he believes that he can postpone the issue of the relation between time and being in consciousness in Ideas I. See, de Boer, The Development of Husserl's Thought, p. 332, n.1. Prior to the publication of Ideas I in 1913, Husserl had of course conducted serious philosophical reflections on this matter in his 1905 lecture-course on immanent time-consciousness at the University of Göttingen, which he had published much later, edited by Heidegger, with Edith Stein's help, in 1928. See, ibid., pp. 462-463.

${ }^{100}$ Husserl, Ideas I, 179:149. We can, of course, recover in memory, through an act of recall (retention), the existence of an experience but in this instance Husserl is unambiguous in noting that in an act of immanent reflective perception the existence is apodictically known of that current experience and that there is a direct perception of the temporality of the actual lived-through experience. This issue of the perception of temporal presence in our experiences can be set aside by Husserl in Ideas I, as establishing the absolute existence of psychical act-experiences (and their objects, if they exist) and co-relative mode of existence of things given to outer perceptual-sense experience is the main focus of the 'reduction'. See, previous, n. 99. This perception of time in psychical act-experiences is not, however, part of Kant's theory - space and time are a priori forms of intuition, not 'phenomena' - but it does become part of Heidegger's reading of Kant's philosophy in his book on Kant, published in 1929.

101 'We must leave theories of this sort on one side, so long, that is, as the need to assume the unbroken activity of inner perception cannot be phenomenologically demonstrated.' Husserl, Logical Investigations, Investigation V, Ch. 1, \5 'Second Sense. "Inner" Consciousness as Inner Perception'.

102 'Every single experience, e.g., an experience of joy, can begin as well as end and hence delimit its duration. But the stream of experiences [for reflection] cannot begin and end. [...] Belonging of necessity to this [ability of consciousness to reflect upon experiences without end] is the possibility (which, as we know, is no empty logical possibility) that the Ego directs its regard to this experience and seizes upon the experience [in reflective immanent perception] as actually existing or as enduring in phenomenological time [of the actual experience].' Ideas I, \81. 'Phenomenological Time and Consciousness of Time,' p. 194:164.

${ }^{103}$ See, Ideas I, \83. 'Seizing Upon the Unitary Stream of Experiences as “Idea”,' pp. 197-199:166-167. The transcendental deduction of the 'idea in Kant's sense' of infinite reflection on such experiences is, therefore, quite a different concept to 'immanent perception' in Husserl's philosophy.
} 
establishment of his conception of phenomenology. It is, therefore, of importance not to confuse, or to mix up these two different kinds of unities in consciousness.

Though experiences are 'ready to be perceived', in any act of reflective immanent perception the whole 'stream of experiences' of course cannot be known, for it is never perceived as a whole. ${ }^{104}$ The past and future parts of the stream are always unknown and, 'in this sense', as Husserl remarks, 'transcendent'. ${ }^{105}$ Yet, it is precisely because we can never in principle embrace the whole stream of experience as a direct object of knowledge and thereby intuit its unity in an act of reflection that we have therein a direct insight into this never-ending possibility as such. ${ }^{106}$ We can then see that reflection on 'the stream of experiences' would continue endlessly, for 'the stream of experience [for reflection] cannot begin and end'. ${ }^{107}$ By comparison to the beginning and the end of an experience as lived, '[reflection on] the stream of experiences [as knowable items] cannot [in principle] begin and end'. It thus follows that recognition of the finiteness of the knowledge of an experience in an act of reflective immanent perception presupposes insight into the ideal-regulative possibility of infinite reflection on the content of that finite experience itself. In other words, we can justifiably deduce from the very finiteness of the knowledge of an experience, immanently perceived, an idea of the unity, totality and infinity of reflection on the existence of such experiences (if, and when they exist) for possible knowledge-claims. This transcendental deduction of the idea of the unity, totality and infinity of reflection on one's actual experiences by the intellectual (and not sense) imagination, Husserl assumes his Kantian readers will readily understand. Concerning the unity of the stream of experiences for reflection, Husserl writes, '(W)e do not seize upon it as we do [the unity of] a single experience [in reflective immanent perception] but in the manner of an idea in the Kantian sense. ${ }^{108}$

Secondly, in Ideas I, Husserl also famously compares the 'outer perception' of a thing (e.g. a table, or an inkpot) to the 'immanent perception' of an experience. Because a thing is spatial in essence, given in adumbration and through perspectival variations, the perception of a thing is always, in principle, incomplete (inadequate) and open to further legitimating experiences of the same kind, that is to say, to further outer perceptual-sense experiences of the thing itself. ${ }^{109}$ By comparison, the '[reflective] immanent perception' of a currently lived experience, because it is not given through perspectival variations, or in adumbration, is always, in principle, complete (adequate). ${ }^{110}$ Husserl, therefore, does not

${ }^{104}$ Ideas I, 'S 45. Unperceived Mental Processes, Unperceived Reality,' pp. 98-100 (p. 99);83-85 (84).

105 See de Boer for the different senses of 'transcendent' that Husserl clearly identifies (The Development of Husserl's Thought, pp. 335-39).

106 Ideas I, 166-7:197-8. See, De Boer, ibid., p. 334, n.5.

${ }^{107}$ Ideas I, 163:194.

${ }^{108}$ Ibid., p. 197:166.

109 See, Ideas I, \41. 'The Really Inherent Composition of Perception and its Transcendent Object' and \44. 'Merely Phenomenal Being of Something Transcendent, Absolute Being of Something Immanent'. Unlike experiences, that are in principle ready to be perceived, reflection on things given to outer perceptual-sense experience "is possible only in the "background field" of my perception, which actually makes up only a small part of the "world around me" (Umwelt)' De Boer, The Development of Husserl's Thought, p. 337. Thus, as de Boer notes, for Husserl, 'the rest [of the world around me] is only perceivable via a long chain of perceptions.' (Ibid.). The transcendence of the stream of experiences for reflection, therefore, is entirely different to the kind of transcendence that characterizes the mode of being of a thing given to acts of outer perceptual-sense experience. 'Husserl', as de Boer also remarks, 'already had made this point a number of times' (ibid.).

${ }^{110} \mathrm{By}$ further comparison, then, the 'thing', because it is given one-sidedly and through perspectival variation, is in principle inadequate and requires the actual harmony of one's actual experiences for that thing, in its very existence and mode of being, to show itself to actual human consciousness. One's own actual consciousness is both a necessary and a sufficient condition for the very existence of the thing given to outer perceptualsense experience. And since, for Husserl, the world is simply the totality of things given to outer perceptualsense experience, the argument extends to the existence of the world: one's own actual consciousness is a necessary pre-condition for its existence. This is one of the most important arguments that Husserl wants to establish in the 'reduction' precisely because if the thing, in its existence, is dependent on the harmony of one's actual experiences, the thing cannot be the ontological basis for the existence of consciousness itself. 
compare (or confuse) the incompleteness characteristic of thing-perception with the incompleteness characteristic of the idea of the infinity of reflection on acts as one commentator suggests, when she comments, '(I)n immanent experience we are faced with an incompleteness that does not occlude the co-appearance of that which appears in its failure to appear, which in turn is fully present [i.e. the idea of infinity of such acts for reflection transcendentally deduced]. In [reflective] immanent experience the infinite fulfilled stream of intentions is fully present despite the incompleteness of the adumbrating nature of lived experiences [i.e., that are characteristic of outer perceptual-sense experiences of things]'. ${ }^{111}$ Given the lack of distinctions by Lilian Alweiss in her commentary on distinctions that are eminently present in Husserl's thought, this author has no alternative but to conclude: 'Reading Ideen I [...] we fail to understand how these claims have come about. How can we simultaneously see incompleteness and completeness?" ${ }^{112}$ We can, however, see how these claims do come about, and understand them, if we distinguish, as Husserl does, between: (1) the incompleteness that is characteristic of thing-perception; (2) the complete unity between perception and its object (which is here an Erlebnis) in an act of reflective immanent perception; and (3) the deduction, on the basis of the recognition of the finiteness of the knowledge-claim of immanent perception as finite, of the idea of infinity for reflection on experiences by the transcendental (intellectual, and not sense) imagination. The transcendental deduction of infinity of reflection on experiences is, then, of crucial significance to Husserl's definition of and belief in 'the infinite task' of phenomenology. His commentators or critics do not always recognize this. ${ }^{113}$ But it is this 'infinite task' of exploring 'psychical phenomena in general' in 'inner perception' that Brentano had intimated in his novel science of 'descriptive psychology' that Husserl sets out to advance and institute in his programmatical unfolding of phenomenology as a systematic science of intentional consciousness and its objectivities.

No matter how infinite in principle reflection on individual actual experiences ideally is, items of knowledge gained by means of reflection on the particularity of the facticity of individual experiences themselves does not and cannot lead to any science of such experiences, so Husserl argues. Reflection, rather, can only be scientific if general truths about the facticity of such experiences are obtainable and communicable for that science. If philosophy is a science - and for Husserl, following Brentano, philosophy is a science, or it is nothing at all - it must arrive at general truths about the facticity of such experiences that are unified and unifiable for that science. ${ }^{114}$ Such general truths, however, cannot be empirical generalisations about matters of fact because all knowledge-claims pertaining to matters of fact, so Husserl argues, again following Brentano, are the purview and provenance of the natural sciences - and philosophy is not a natural science - but eideticgeneral truths about that which cannot be otherwise, i.e., eidetic-ontological laws pertaining to (lived) experiences are obtainable. Only a descriptive-eidetic manner of reflection can realize the possibility of philosophy as a universal science that is rigorously and

Thus any reification or naturalistic conceptions and misunderstandings of consciousness are refuted, philosophically. See, de Boer, The Development of Husserl's Thought, 'paragraph nine: consciousness as the necessary condition and sufficient reason of the world', pp. 354-357.

${ }^{111}$ Lilian Alweiss, The Unclaimed World: A Challenge to Heidegger's Critique of Husserl (Athens, Ohio: Ohio University Press, 2003), \20. 'Limitations of Ideen I,' pp. 32-33 (p. 32).

112 Ibid.

113 The transcendental deduction of the infinity of reflection on experiences is of critical significance to Husserl's definition of 'the infinite task' of phenomenology, but it should not be confused with other parts of his philosophy. It should not, however, be overlooked either, as it is by one author, in a chapter of a recent book on Husserl, entitled 'Chapter 6 Transcendental Phenomenology: An Infinite Project', where no account at all of Husserl's deduction of the idea, in the Kantian sense, of the infinite task of reflection on experiences is given. Cf., Moran, Edmund Husserl: Founder of Phenomenology (2005), pp. 174-201.

114 See, Husserl, 'Introduction', to Logical Investigations, Vol. II, Part I of the German edition, '\$7 "Freedom from presuppositions" as a principle in epistemological investigation'. 
phenomenologically legitimated. ${ }^{115}$ It thus follows for Husserl that it will be a strict methodological requirement for 'descriptive psychology' to seek out and discover only those universally determinable, essential features of experiences themselves, ignoring whatever contingencies there are pertaining to the facticity, temporality, historicity and idiosyncrasies of such experiences, in the elaboration of Brentano's new science of 'descriptive psychology', that is to say, as 'descriptive-eidetic-psychology' or 'phenomenology'. ${ }^{116}$

It thus turns out to be the case that the ability of consciousness to reflect upon itself, and therein attempt to grasp its essence, is a Lockean assumption that both Brentano and Husserl hold, but unlike Locke and Brentano this ability, as Husserl correctly argues, is not a legitimate methodological basis for a new science that purports to be a science of the essential features of consciousness and its objectivities. Knowledge of the essential features of psychical act-experiences and their objects (if they exist) is a product of eidetic insight into, or eidetic abstraction from factual experiences, of 'eidetic ideation' as he calls it in the Logical Investigations, or 'eidetic variation' as he calls it in Ideas I. Thus Husserl can accept Brentano's claim that all our knowledge of consciousness comes from whatever particular experiences of consciousness we have, from acts of inner perceptions of our own psychical act-experiences, but reject his view that the scientific basis to Brentano's own novel a priori science of descriptive psychology is confined to and derived from those particular experiences (inner perceptions) themselves. The basis, rather, lies in the intuitive grasp of the intelligible structure of such factual experiences, and this is a product of intuitive insight into the universal features of such experiences. 'Back to the things themselves', for Husserl of the Logical Investigations, is back to these essential structures of consciousness and its objectivities themselves. This is why Husserl can argue, again correctly, that the experiential origins of all a priori judgements, such as, for instance, the a priori judgement 'Colour implies extension', cannot be founded in the inner perceptions [factual reflections on] of colours (or coloured things) - no amount of factual perceptions of colours as extended can justify that colours not perceived are extended - but positive grasp of colour itself, as a general object: some positive, identifiable experience of colour itself as a universal object, is the basis of this a priori judgement. Whether we mistake a green apple for a green pear, we know 'this green' is not 'that green', that 'there are no coloured things/ colours that exist that are not extended', and that 'colour in essence is extended'. In this regard, colour, as a general object, is no more mysteriously presented to consciousness than colours, but it is presented to consciousness via a particular new mode and kind of act of consciousness, of eidetic insight or eidetic ideation, and not through sensuous intuitions of particular

115 'The study of the stream of experiences is, for its part, carried on in variety of peculiarly structured reflective acts which themselves also belong to the stream of experiences and which, in corresponding reflections at a higher level, can be made the Objects of phenomenological analyses. This is because their analyses is fundamental to a universal phenomenology and to the methodological insight quite indispensable to it (unentberliche methodologische Einsicht).' Ideas I, p. 177:147. This marks Husserl's major methodological advancement of Brentano's idea of descriptive psychology (which, following Hume, finds its basis solely on individual inner perceptions) to a descriptive-eidetic science, though Husserl is quite right to note that Brentano (who denied the existence of any such fictional entities as 'essences') could not see this as the fruition of his own ideas. See, Husserl, 'Reminiscences of Franz Brentano', p. 50, and Ideas I, pp. xx:3-4. Husserl had already arrived at this conclusion, which he also calls his 'breakthrough' (to descriptive-eidetic psychology) in his Logical Investigations, of course: 'Assertions of phenomenological fact can never be epistemologically grounded in psychological experience (Erfahrung), nor in internal perception in the ordinary sense of the word, but only in ideational, phenomenological inspection of essence. The latter has its illustrative start in inner intuition, but such inner intuition need not be actual internal perception or other inner experience (Erfahrung), e.g. recollection: its purposes are as well or even better served by any free fictions of inner imagination provided they have enough intuitive clarity.' Logical Investigations, Investigation V, \$27 The Testimony of Direct Intuition. Perceptual Presentation and Perception.

116 See, Ideas I, 575. 'Phenomenology As a Descriptive Eidetic Doctrine of Pure Experiences', and previous n. 115. 
colours. ${ }^{117}$ To deny the 'reality' of colour, Husserl argues, is not to deny its 'objectivity'. Colour, as a general object, is given, 'so to say' (sozusagen), in its bodily living reality about which true judgements can be made, e.g., colour implies extension, colour is not sound, and so forth. ${ }^{118}$ The analogy that connects colour as a general object to consciousness that Husserl appeals to is the analogy of givenness for perception. ${ }^{119}$ Husserl is not saying that 'colour' (as a general object) is a living body, or that it is given to an act of outer perceptualsense experience, but that colour (or sound) is given as a general object to perceptual experience in no more or less a mysterious way than colours (that are not living bodies either) are given to outer perceptual-sense experience. ${ }^{120}$ On this basis, Husserl can claim that 'we', that is to say, those who affirm the existence of essences as givens of experience, 'are the genuine positivists'. ${ }^{121}$ Alas, Brentano could not see this as a development of his method, or as any form of 'empiricism' whatsoever, but as an aberration of his natural science of descriptive psychology that finds it methodological origins in 'inner perceptions' (factual reflections on particular experiences). For Brentano, following his Aristotelian prejudice, only particulars exist and can exist, 'inner perception tells me that I am seeing [only] this or [only] that colour, willing [only] this'. Inner perception tells me nothing about 'colour' or 'sound'. Thus, in Brentano's eyes, and in many other eyes at the time, Husserl's defence of the existence of 'essences' is, at best, fictional, at worse, a return, by Husserl, to some form of Platonism. ${ }^{122}$

Husserl, then, rejects the epistemological claims that Brentano makes for his method of inner perceptions/ inner reflections as the method to be employed in the new science of descriptive psychology but on the experiential basis that essential features that cannot be otherwise are the direct objects of such a science. Thus the division between eidos and fact must be maintained in order to justify the validity of descriptive a priori knowledge-

\footnotetext{
117 'Intuiting essences', Husserl remarks in his 1910-11 Logos essay 'Philosophy as Rigorous Science', 'conceals no more difficulties or "mystical" secrets than does perception. When we bring "colour" to full intuitive clarity, to givenness for ourselves, then the datum is an "essence"; and when we likewise in pure intuition looking, say, at one perception after another - bring to givenness for ourselves what "perception" is, perception in itself (this identical character of any number of flowing singular perceptions), then we have intuitively grasped the essence of perception. As far as intuition - i.e., having an intuitive consciousness extends, so far extends the possibility of a corresponding "ideation" (as I called it in Logische Untersuchungen), or "seeing essence".' Husserl, 'Philosophy as Rigorous Science', in Edmund Husserl, Phenomenology and the Crisis of Philosophy, trans. by Quentin Lauer (New York: Harper \& Row, 1964), pp. $71-147$ (pp. 110-1); 'Philosophie als strenge Wissenschaft', Logos, 1 (1910-1911), 289-341. See, also, Husserl, Ideas I, \ 3.

118 Husserl, Ideas I, \24. 'The Principles of All Principles'.

119 Thus 'the meaning of language', as de Boer succinctly points out, 'is determined exclusively by what is seen. It is a "faithful expression of clear givens". Thus there really is a "point of contact".' The Development of Husserl's Thought, p. 378.

120 The primary analogy for Husserl here is the givenness for perception and not the bodily presence of one's fellow human being. Levinas departs completely from any such founded mode of perception as the legitimate phenomenal basis to approach the otherness of the other that we do encounter 'face to face' via dialogue, for, even when we are talking to another person about that person herself, the otherness of the other discussed is more than that and stands behind that. That Husserl can regard 'Colour' as an universal object that is given in its 'living bodily reality' (in seiner leibhaften Wirklichkeit), 'present in the flesh', 'in propria persona' to (eidetic) perception should be enough to alert commentators to the dominance of perception - and not to the full presence of the living body of a fellow human being — in the analogy used here by Husserl and in Husserl's thought. Cf., however, Moran, Edmund Husserl: The Founder of Phenomenology, p. 266, n.37. Thus the inclusion of universal objects (e.g. colour) about which we can and do make eternally true a priori judgements (e.g. colour implies extension), that are given to eidetic ideation or intuition 'in their bodily reality so to speak', which Husserl famously expounds in his advancement of a descriptive-eidetic-psychological method in the 'principle of all principles' (Ideas \$24), can fare, in principle, no better in addressing the way perception of the body of another or of our selves plays a crucial role in any knowledge of others and of one's self.

${ }^{121}$ Husserl, Ideas I, p. 39:38.

122 There was much talk of the 'Platonism' of Husserl's Logical Investigations. See, de Boer, Development of Husserl's Thought, Part Two, Ch. III, \10. Husserl's “Platonism” or “Realism”, pp. 260-269.
} 
claims, and to avoid all forms of psychologism. ${ }^{123}$ Whether Husserl's doctrine of the 'intuition of essences' is a return to Platonism can be set aside, but it is, as Heidegger correctly comments, a defence of some form of a priori empiricism (that is not 'an " $a$ priorisitic" construction'). ${ }^{124}$ And it is through this doctrine that Husserl can provide the kind of presuppositionless starting-point that Brentano himself seeks in PES but cannot find, or, at least, can only find in the assertoric-factual judgements of individual psychical actexperiences given in acts of inner perceptions (reflections).

\section{(i) Perception as Incidental Consciousness}

Besides the above three meanings that Brentano appears to subscribe to for inner perception', namely, as (1) the Lockean hypothesis of an accompanying, supervening act of inner perceiving all conscious acts, or (2) as an act of reflection (upon psychical actexperiences), or (3) as a reflective immanent perception, in PES Brentano operates with a fourth meaning of 'inner perception' as (4) 'incidental consciousness' (Bewusstsein nebenber) (which he also calls 'inner consciousness' and 'secondary consciousness'). ${ }^{125}$ This consciousness, Brentano argues, accompanies 'incidentally' each and every conscious act I have. Every conscious act exists only if there is also the awareness of being aware as an integral part of each and any conscious act that actually exists. This is why Brentano remarks that such incidental awareness 'is an accessory feature included in the act itself. ${ }^{126}$

According to Brentano, each and every conscious act, which a mentally active subject experiences, is accompanied by an 'incidental awareness' (nebenbei Bewusstsein) of itself as a conscious act. This awareness of being aware, although 'incidental' is, nonetheless, Brentano argues, an 'essential ingredient' in any presentation (Vorstellung) because it is 'connected [...] in such a peculiarly intimate way that its very existence constitutes an intrinsic prerequisite of the existence of this presentation. ${ }^{127}$ Hence, 'we divide it [ $=$ a conscious act of hearing, as is evident from the context $]$ conceptually into two presentations', but in reality, this presentation contains (1) the act of hearing (psychical actexperience), (2) the object heard (the 'sound' qua physical phenomenon) and (3) the awareness of being aware (incidental consciousness) as part of that very conscious act. ${ }^{128}$

For Brentano, then, incidental consciousness is a feature of the acts of consciousness, not of the objects of consciousness. This incidental or additional consciousness, however, Brentano stresses, is not an attentive act of perceiving or some

\footnotetext{
${ }^{123}$ Brentano was particularly offended when charged of 'psychologism' by Husserl, since Brentano appeals solely to the 'evidence' of an act of (true) judgement, but they are different forms of psychologism, not all of which Brentano escapes. See, de Boer, The Development of Husserl's Thought, Part I, Ch. VI 'Preliminary Conclusions', 'paragraph one: philosophy as descriptive psychology — forms of psychologism', pp. 115-117 and Part Two, Ch. VI Conclusions, $\mathbb{\int}$ 2. 'Forms of Psychologism', pp. 300-301.

${ }^{124}$ Cf., Being and Time, \$10. 'How the Analytic of Dasein is to be Distinguished from Anthropology, Psychology, and Biology', esp., n. 10. In the Logical Investigations, the existence of ideal meanings, what Husserl calls 'essences', is defended on the basis of descriptive-eidetic-psychological analysis of the experiences of a normatively valid logical consciousness as such. Corresponding to general meanings that are uttered or expressed in logical statements, there are general essences upon which the gaze of a valid logical consciousness rests. If one wishes to call this the 'realism' or 'Platonism' of the Logical Investigations, as it was at the time, then so be it. See Husserl's response to this interpretation in Ideas $\int 22$. 'The Reproach of Platonic Realism. Essence and Concepts'. (pp. 40-42:40-42) 'I did not invent the universal concept of object; I only restored the concept [in the Logische Untersuchungen] required by all propositions of pure logic and pointed out that it is an essentially indispensable one (daß er ein prinzipiell unentbehrlicher) and therefore that it also determines universal scientific language (und daher auch die allgemeine wissenschfliche Rede bestimmender ist).' ( $\mathrm{p}$. 41:40) Cf., also, Levinas, The Theory of Intuition in Husserl's Phenomenology, p. 97 and De Boer, The Development of Husserl's Thought, pp. 263-269.

${ }^{125}$ Cf. PES, Book II, Chapter II Inner Consciousness, p. 101 and ff., and Chapter III Further Considerations Regarding Inner Consciousness, p. 138 ff. See, also, DP, p. 25.

126 PES p. 141.

127 Ibid. p. 127.

128 Ibid.,p. 127, my emphasis.
} 
kindred act of introspection or inner observation. ${ }^{129}$ Such incidental awareness, rather, is an 'accessory feature included in the act itself. ${ }^{130}$ Incidental awareness 'is not a self-sufficient act', but, as de Boer remarks, 'is of an accompanying [parasitic] character.' ${ }^{131}$ Nevertheless, this incidental awareness, Brentano argues, is connected 'in such a peculiar intimate way' to each and any conscious act, that its very existence constitutes an intrinsic prerequisite for the existence of a conscious psychical act-experience. ${ }^{132}$ That a conscious act is a conscious act, that is to say, that it contains an incidental awareness of itself as a conscious act, is part of the very act. It would be self-referentially inconsistent for anyone to deny such incidental awareness, because a conscious act of denial, as a fact of experience, presupposes its validity. Hence, Brentano concludes, 'the truth of inner perception [as incidental consciousness] cannot be proved in any way, ${ }^{133}$ but this is because 'it has something more than proof; it is immediately evident.' 134 Though immediately evident, such '[incidental] awareness', as Spiegelberg correctly points out, '[is] restricted, to be sure, to the immediate present' and hence, 'would seem to be infinitesimally small'. ${ }^{135}$ It is, nonetheless, an essential ingredient of a conscious act without itself being a conscious act or a definable object of any (intentional) conscious act. Thus '( $T$ )he unity of consciousness', as Brentano correctly argues, 'does not require either the simplicity or the indivisibility of consciousness. ${ }^{136}$ For instance, in a conscious act of hearing, the awareness of being aware, the immanent object of that conscious act (a sound qua physical phenomenon) and the act of hearing (the psychical act-experience) are all 'real' components of an actual conscious act of hearing.

Brentano's doctrine of 'incidental consciousness', however, has caused much anguish among commentators and critics of his thought. B. Terrell, for example, remarks,

All mental phenomena include an awareness of themselves according to Brentano's doctrine of inner perception or secondary consciousness. Inner perception as a component feature of a mental phenomenon must therefore be distinguished from any mental act, including so-called introspection, that has another such phenomenon as its primary object reference [...]. There has been relatively little examination of this aspect of Brentano's philosophy of mind that goes beyond either the mere restatement of this doctrine or an expression of despair of understanding it. ${ }^{137}$

One of the main reasons for so much obscurity, confusion and even 'despair' at understanding Brentano's doctrine on 'inner perception' is, no doubt, his indiscriminate and equivocal use of the term 'inner perception'. And when commentators and critics duplicate Brentano's equivocations, his philosophy appears full of inconsistencies and ambiguities. ${ }^{138}$ When inner perception refers to the awareness of being aware, Brentano,

\footnotetext{
${ }^{129}$ Ibid.,p. 30.

130 Ibid., p.141, my emphasis.

${ }^{131}$ De Boer, The Development of Husserl's Thought, p. 36.

132 PES, p. 140.

133 Ibid.

${ }^{134}$ Ibid.

135 Spiegelberg, The Phenomenological Movement, (1994), p. 36.

136 PES, p. 171.

137 B. Terrell, 'Brentano's Philosophy of Mind', in Contemporary Philosophy: A New Survey. Philosophy of Mind, Vol. 4, ed. by G. Fløistad (The Hague: Nijhoff, 1983), pp. 223-248 (p. 223).

138 Moran thinks that 'Brentano's reliance on the additional consciousness account [...] concerning the unity of the act and the nature of its object', which commits Brentano to the view that '(B)eing an object of an act is not exhausted by being physical or even sensory, since we can have a mental act as an object', renders 'Brentano's very notion of physical and psychical phenomena [...] largely incoherent', and so, '(T)he whole account [of the distinction between physical and psychical phenomena] seems shot through with confusion'('The Inaugural Address: Brentano's Thesis', pp. 21-2); David Bell expresses similar views in Husserl (London: Routledge, 1991), p. 9. Moran does not modify this account of Brentano's doctrine of 'additional consciousness' given in 'The Inaugural Address: Brentano's Thesis', in his widely used and reissued study Introduction to Phenomenology (London: Routledge, 1999; eBook, 2007, pp. 43-45). If, however, we distinguish different concepts of inner perception that Brentano appears to subscribe to, namely, as (1) the Lockean hypothesis of an unbroken and automatic inner percept of conscious acts, (2) inner reflection, (3)
} 
nonetheless, is crystal clear as to where he obtained this doctrine: not from Locke, nor from Descartes, but from Aristotle, and quotes in PES exactly where Aristotle in the Metaphysics remarks,

Knowledge, sensation, opinion and reflection seem always to relate to something else, but only incidentally to themselves. ${ }^{139}$

This quote is a very important quotation. Some commentators of Brentano's thought see in this quote not only Brentano's faithful adherence to Aristotelian philosophy, but also the Scholastic roots of Brentano's celebrated 'realist' thesis of the intentionality of consciousness, that is to say, the view that consciousness is always related to something other than itself. ${ }^{140}$ This, however, is not Brentano's position in PES, for what consciousness is a consciousness of, from a descriptive-psychological methodological point of view, is, as we have noted, psychical act-experiences themselves. Sensation is not directed towards physical things extra-mentally but colours, sounds etc., qua immanent, intentional (mental) objects that only exist as long as the act of outer perceptual-sense experience exists. This part of Brentano's doctrine of intentionality is completely 'unScholastic', and Brentano adapts and changes significantly the meaning of the ScholasticAristotelian concepts of intentional in-existence, intentional act and intentional object in the elaboration of his new science of descriptive psychology. ${ }^{141}$ Brentano, however, does not deviate from the Aristotelian view that every conscious act is aware of itself incidentally. Indeed, in his commentary on this part of Brentano's doctrine on inner perception' Husserl, in his 'Appendix', stresses the point that such incidental awareness is 'no second, independent act supervening upon a relevant psychic phenomenon'. ${ }^{142}$ Rather, insofar as 'the act directly intends its primary object, it is also subsidiarily directed upon itself.' 'In this way,' Husserl continues, in entire agreement with Brentano, 'one avoids the endless complication of all psychic phenomena. ${ }^{143}$ Brentano, then, is correct to insist that such incidental awareness is not an act of inner observation (or outer observation). And Husserl can acknowledge the validity of this Aristotelian tenet in Brentano's descriptive account of conscious, psychical act-experiences, while rejecting Brentano' Lockean theory that all psychical act-experiences are accompanied by an inner act of perceiving. Incidental awareness, nonetheless, is not an act of (inner or outer) perception. It is very unfortunate, therefore, that Brentano calls it an 'inner perception', but his reason for doing so is because such a feature is an intrinsic feature of a conscious act and something that is evidently and directly known to be the case though neither as an object nor as an act of consciousness itself. Incidental awareness, nonetheless, is not an act of inner reflection either. As Heidegger remarks to his students in his 1951-1952 lecture course on What is Called Thinking?,

immanent perception, and (4) incidental awareness, Brentano's doctrine is not as confused as it is portrayed by these commentators. Even if we do not distinguish these in Brentano's thought, Bartok makes the point that Brentano's account of 'inner perception' is not as incongruent as both Bell and Moran suggest since 'given the metaphysical and epistemological framework in which descriptive psychology is constrained to operate, it cannot be the descriptive psychologist's mandate to develop anything like a "theory" of intentionality or inner perception in the traditional sense' ('Brentano's Intentionality Thesis', p. 450).

139 PES, p. 132, quoting Aristotle, Metaphysics Bk XII 9. See, also, DP, p. 25 ('geht nebenher auf sich selbst', p. 22). Brentano does not supply textual reference here, as he did in PES, but the one supplied by the editors from Aristotle's De Anima, III, Ch. 2, 425b, (DP, p. 180, n. 10) is incorrect.

${ }^{140}$ Cf., Ausionio Marras, 'Scholastic Roots of Brentano's Conception of Intentionality', in The Philosophy of Brentano, ed. McAlister, pp. 128-139 (p. 136).

${ }^{141}$ See, McDonnell, 'Brentano's Revaluation of the Scholastic Concept of Intentionality into a Root-Concept of Descriptive Psychology', esp., pp. 155-165.

${ }^{142}$ Husserl, 'Appendix', p. 858.

143 Ibid. 
When we attempt to learn what is called thinking and what calls for thinking, are we not getting lost in the reflection that thinks on reflection? Yet all along our way a steady light is cast on thinking. This light is not, however, introduced by the lamp of reflection. It issues from thinking itself, and only from there. Thinking has this enigmatic property, that it itself is brought to its own light though only and as long as it is thinking, and keeps clear of persisting in a ratiocination about ratio. ${ }^{144}$

Like Brentano and Husserl, then, Heidegger too appears not to reject Aristotle's 'incidental awareness' thesis.

Though incidental awareness is an irrefutable, irrefragable, irreducible accompanying feature of each and any actual conscious act that exists for the mentally active subject, such incidental awareness, as Husserl is quick to point out, can be of no value to any science in obtaining any knowledge about anything. The awareness of being aware necessary as it is for the very existence of conscious acts as conscious acts - is an inattentive act. Such awareness of being aware cannot be employed by any scientist to gain knowledge of any thing, never mind by a descriptive psychologist to gain knowledge of psychical actexperiences. As Spiegelberg comments, 'His [the descriptive-psychologist's] only comfort would be that he shares his plight with all other scientists. ${ }^{145}$ There is, then, in sum, nothing of scientific benefit in this fact. Central as this doctrine of 'incidental awareness' is to Brentano's account of the unity of consciousness, it can play no methodological role in the development of descriptive psychology as a science, and so, drops out of Husserl's development of Brentano's conception of philosophy as the descriptive science of psychical act-experiences and their objectivities.

\section{CONCLUSION}

We can and must distinguish four different concepts of 'inner perception' in Brentano's thought in order to remove some of the obscurity that surrounds his doctrine.

Firstly, inner perception is regarded by Brentano as an inner act of perceiving that accompanies each and every psychical act-experience that befalls the mentally active subject. This theory Brentano borrows from Locke but it is rejected by Husserl on the basis that there is no evidence in our experience to support such a hypothesis.

Secondly, by inner perception, Brentano also means the ability of the mentally active subject to turn attention away from 'physical phenomena' (or 'things') given to outer perceptual-sense experience and towards psychical act-experiences themselves correlated to their objectivities, in order to describe what such experiences are themselves, without appealing to any natural scientific, or any other kind of hypothetical or causal line of reasoning. This form of reflection is the method that Brentano allots to descriptive psychology and it is an essential part of the elaboration of concepts in Brentano's new science of descriptive psychology. From a methodological point of view, it is only when inner perception refers to such inner, intuitive reflection that it denotes the descriptive method to be employed in the science of descriptive psychology. How such inner reflection that is directed towards one's own particular individual psychical act-experiences can produce $a$ priori knowledge-claims about psychical act-experiences in general, is an issue that Brentano does not explain. It is a problem that occupied Husserl's thought, and leads to Husserl's' development of his theory of the intuition of essences.

Thirdly, by inner perception Brentano means the 'reflective immanent perception' of a currently lived, psychical act-experience. This plays a critical role in Husserl's famous transcendental reduction in Ideas I, but is left 'unthought', to borrow Heidegger's expression, in Brentano's descriptive psychology.

${ }^{144}$ Heidegger, What is Called Thinking?, trans. by F. D. Wieck and J. Glenn Gray (New York: Harper and Row, 1968), p. 28; originally published as, Was heißt Denken (Tübingen: Niemeyer, 1954).

145 Spiegelberg, The Phenomenological Movement, (1994), p. 36. 
Fourthly, by inner perception Brentano also means the awareness of being aware which accompanies incidentally all conscious acts. This is an intrinsic feature of any conscious act, but it is not a self-sufficient conscious act. It is not a 'psychical phenomenon' or a 'psychical act-experience', as both Brentano and Husserl define those terms. It should not, therefore, be labelled as an act of perception, or of judgement, or of reflection, or of attention, or of any other identifiable psychical act-experience simply because it is not an identifiable act-experience at all. Neither is it a 'physical phenomenon' (in whatever way this term is understood, either as a sensorial quality of acts of outer or inner sense perception, or as a theoretically constructed object of physics, or an identifiable object of outer sense perception, e.g., a drop of water). It is, rather, an accessory feature of all conscious acts and correctly understood by Brentano to be a necessary pre-requisite for the existence of a conscious act. A conscious act simply could not be a conscious act without the awareness of being aware as a feature of that act. This feature, then, is an intriguing dimension to conscious acts, and one that Husserl does not reject, but since such awareness is an inattentive act, no use of it, as Husserl again correctly argues, can be made methodologically in the science of descriptive psychology. ${ }^{146}$

Notwithstanding the four meanings of 'inner perception' that Brentano seems to subscribe to, if we accept Brentano's claim (following Locke and Hume) that the way we come to any knowledge about our human consciousness is by reflecting on the contents of consciousness itself, then Husserl is right to stress the point that this begins with a choice. One can choose to reflect upon one's own psychical act-experiences in the search for essential features of those very experiences themselves - 'the things themselves' for Husserl, at the time of his writing of the Logical Investigations, are such 'essences' — and thus develop Brentano's new science of descriptive psychology into a descriptive-eidetic science that is not and cannot be founded in inner perceptions (reflections) on actual experiences. Inner perceptions of one's own experiences, however empirically certain or psychologically indubitable, can never in principle provide a sufficient or proper experiential basis for the justification of a priori knowledge-claims, but the intuition of 'essences' can and does do this. ${ }^{147}$ The will-to-science, as long as it is correlated with intelligible 'essences' grasped

\footnotetext{
146 Regarding Brentano's doctrine of 'additional consciousness' (Bewusstseinsnebenber), Moran, in a section entitled 'Inner perception as additional awareness' in 'Chapter I Franz Brentano: Descriptive Psychology and Intentionality' of his An Introduction to Phenomenology, remarks, '(T)hough he rejected introspection, Brentano believed that he could achieve direct knowledge of his inner mental states, by catching these states reflectively while engaged in acts of outer perception. All consciousness of an object is accompanied by a consciousness of itself as act, though this need not be explicit. There is no perceiving without the possibility of apperception (DP, p. 171; PES, p. 153) and hence, for Brentano, there can be no unconscious mental acts. Brentano drew on Aristotle and Thomas Aquinas for a description of the nature of this accompanying, concomitant, or "additional consciousness" (Bewusstseinsnebenbei), whereby the essential features of the primary act are grasped "by the way", "incidentally" (per accidens, en parergo, PES p. 276). [...] In Brentano's language, we apperceive ourselves having perceptions, we cannot observe these perceptions directly' (p. 43). Thus Moran concludes, '(I) $\mathrm{n}$ a sense, Brentano weds the Aristotelian account to the Cartesian-Leibnizian view that inner perception is apodictic, given with certain "self-evidence" (Evidenz)' (ibid.). And the author immediately adds, '(I)t is important to realise how restrictive descriptive psychology is. Our immediate infallible knowledge is restricted to the present moment, to the now' (ibid.). The awareness of being aware that accompanies a conscious act, however, is not an attentive act, nor is it an act of reflection, nor can it grasp [know] essential features of the primary act, nor even know that the act exists, i.e., the singular existence of that primary act. It is, rather, an intrinsic feature of a conscious act with no cognitive import. Moran, however, is quite correct, as is Spiegelberg in The Phenomenological Movement (p. 36), in noting that incidental awareness is limited strictly to the present. This must not be confused, however, with '[reflective] immanent perception', which is also limited to the present and is apodictic, as Husserl correctly points out. 'Additional consciousness' or 'incidental awareness', nonetheless, is of no use in the science of descriptive psychology, as Husserl correctly argues.

${ }^{147}$ Brentano, of course, could not see this. Cf., his remarks directed against this 'Supplementary Remarks', IX 'On Genuine and Fictitious Objects', pp. 291-301 (p. 297). According to Brentano's theory of judgment, necessarily true, universal affirmative judgments do not posit the existence of their objects, but are convertible to negative existential judgments, e.g., the a priori judgement colour implies extension is convertible (and identical in meaning and truth-value) to the negative existential judgement: there are no
} 
through intuitive reflective insight, opens up the possibility of collaboration in a new science of consciousness and its objectivities; or, at least, so Husserl was convinced, following Brentano's descriptive-psychological science, but departing from the inessential basis of factual inner perceptions (much to Brentano's incomprehension and disappointment), in his advancement of his 'method' of phenomenology as a radical, selflegitimating, descriptive-eidetic science of pure intentional consciousness and its objectivities. This is why Husserl is correct, in his self evaluation, to tell his students in his 1925 Summer-Semester lecture course on Phenomenological Psychology that his efforts in philosophy and phenomenology to pursue descriptive-eidetic science of pure consciousness and its objectivities was a radicalization of ideas he found in Brentano, but that 'Brentano himself did [could] not [methodologically] recognise it as the fruition of his own ideas'.

What Husserl himself, however, seems to overlook is that his understanding of the very ability of consciousness to reflect upon itself and to have itself as a 'content of reflection', to borrow Husserl's phrase from the Logical Investigations, presupposes a dualistic metaphysics of human subjectivity, in terms of a lucid mind and opaque body, and until this metaphysical remnant was to be displaced with an existential-phenomenological methodological starting-point, the desired goal of understanding the significances of the meaning of experiences characteristic of actual buman consciousness as such could not be fully realised. Perhaps the Husserl of Ideas I, nonetheless, has a point when he argues that it takes a special way of looking at human consciousness to unlock buman consciousness, to overcome the absolutization of nature and the reification of consciousness, and to enable human consciousness to come into view at all for analysis. And when it does come into view for analysis, if universal truth is sought, then the only way to pursue such a descriptive science will be to engage in reflective intuitive insight into the essential features of the experiences of a human being, as Husserl argues. Whether the significances of the particularity (facticity) of those very experiences of a human being are overlooked in this very search for universal, essential a priori features, is, however, a critical point that Dilthey (before Heidegger) made against Husserl's method of eidetic analysis (and against both the natural science method of analysis and the Lockean-Humean-Brentanian method of inner perception'). Addressing this critique, however, takes us out of the methodological concerns for 'science' and 'research', of 'inner perception' and 'inner reflection', and of 'eidetic insight' that are characteristic and definitive of the thought of Brentano and Husserl, and into an alternative method of analysis for philosophy that can never in principle be a science (nor a system) but a permanent act of hermeneutic retrieval of the significances of the meaning of the uniqueness of life experiences that is found in those experiences themselves and that are expressed in those experiences themselves in language, in a play, a poem, a prayer, a work of art, a hymn, and in all 'objects' of culture, as advocated by Schleiermacher and developed by Dilthey. Husserl, however, follows Brentano (the descriptive psychologist),

unextended colours (or coloured things), or a hypothetical positive judgement, if a colour (or coloured thing) exists it is unextended. Herein, Brentano thinks he retains his 'descriptive psychological' view point that the sole basis in experience for the truth of this judgment is actual outer perceptual-sense experience of colours (or coloured things). This is why Brentano thinks he needs no such fictitious general object as 'colour' to exist in order to justify, in experience, the truth of the a priori judgment 'colour implies extension'. Knowing the truth of the fact that colours are extended in any particular act of judgement now, however, cannot guarantee necessarily that possible colours (or colours things) might exist as unextended, yet this is exactly what is excluded by the a priori judgement. Husserl notes that the a priori judgment implies some direct experience of colour itself as a general object and insight into its essence is the basis in experience upon which the truth of the a priori judgement rests and that is valid not only for actual but all possible experiences of colours/ coloured things. Hence his remark, ' $(N)$ o interpretative skill in the world,' alluding to Brentano's conversion of universally valid a priori judgements into particular negative existential judgements, 'can in fact eliminate [these] ideal objects from our speech and our thought.' Logical Investigations, vol. 1, p. 353, my emphasis. This is also what lies behind Husserl's later insistence in 'Part One: Essence and Eidetic Cognition' of Ideas I that, 'we are the genuine positivists' (p. 39:38). 
and not Dilthey (the descriptive psychologist), in affirming priority to the way in which consciousness can, in light of reflection upon its own self, know itself and deduce its freedom and responsibilities from reflecting upon itself. In this regard, Husserl, is quite right to note in his self-evaluation (regardless of the so-called followers of his thought) that his particular definition and way of doing phenomenology follows, methodologically, in the wake of Brentano's new science of descriptive psychology, even if Brentano himself could not and did not see this as a continuation of his own ideas. ${ }^{148}$

${ }^{148}$ I would like to thank very much indeed the reviewer of this article for the close reading, comments and corrections made to some of my errors and that were most helpful to me - any existing errors, of course, are entirely my own. 